\title{
‡USGS
}

Euses

Prepared in cooperation witib ilie Pierto Rico Aqueduct and Sewer Authority, Puerto Rico Department of N atural and Envifonmental Resources, and Puerto Ritco Environmental Quality Boaral

\section{Estimated Water Use in Puerto Bjeo, 2010}
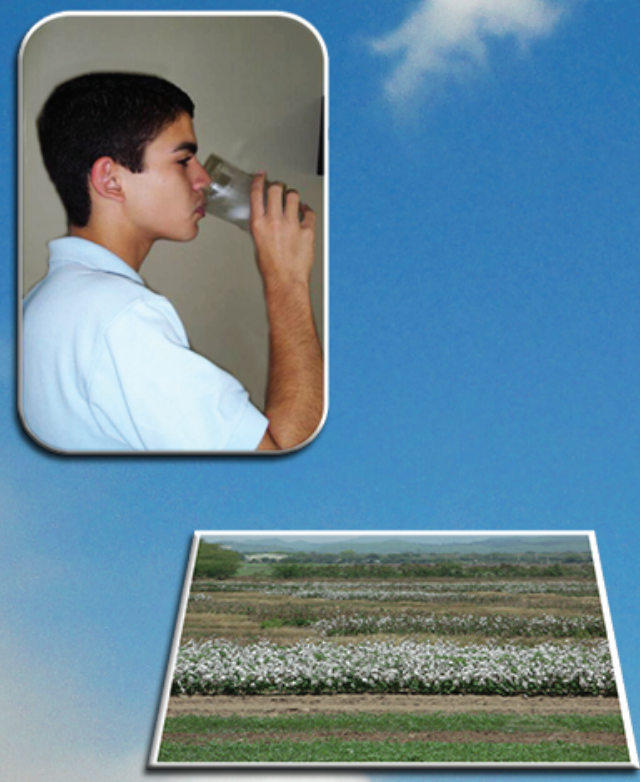

Open-File Report 2014-1117

U.S. Department of the Interior U.S. Geological Survey

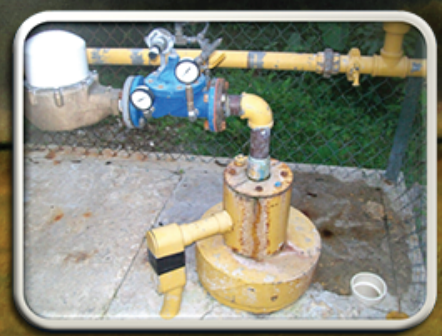




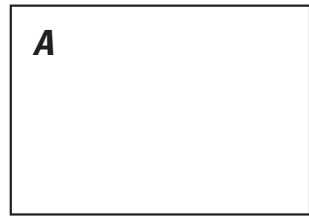

B

C

D

$\boldsymbol{E}$

Cover. From top to bottom: $A$, example of consumptive use, photograph by Wanda L. Molina, January 30, 2009; $B$, cotton crops in the south coast of Puerto Rico, photograph by Marcos Quiñones, April 13, 2012; $C$, example of surfacewater intake located in southeastern Puerto Rico, photograph by Jessie Juarbe, September 13, 2013; $D$, example of household water use, photograph by Wanda L. Molina, January, 2009; $E$, example of plumbing configuration used by domestic wells in Puerto Rico, photograph by Jessie Juarbe, July 18, 2011. Background image: farm irrigated by a sprinkler system in the south coast of Puerto Rico, photograph by Marcos Quiñones, February 24, 2014. 


\section{Estimated Water Use in Puerto Rico, 2010}

By Wanda L. Molina-Rivera

Prepared in cooperation with the

Puerto Rico Aqueduct and Sewer Authority,

Puerto Rico Department of Natural and Environmental Resources, and

Puerto Rico Environmental Quality Board

Open-File Report 2014-1117

U.S. Department of the Interior

U.S. Geological Survey 


\title{
U.S. Department of the Interior SALLY JEWELL, Secretary
}

\section{U.S. Geological Survey \\ Suzette M. Kimball, Acting Director}

\author{
U.S. Geological Survey, Reston, Virginia: 2014
}

For more information on the USGS - the Federal source for science about the Earth, its natural and living resources, natural hazards, and the environment, visit http://www.usgs.gov or call 1-888-ASK-USGS.

For an overview of USGS information products, including maps, imagery, and publications, visit http://Www.usgs.gov/pubprod

To order this and other USGS information products, visit http://store.usgs.gov

Any use of trade, firm, or product names is for descriptive purposes only and does not imply endorsement by the U.S. Government.

Although this information product, for the most part, is in the public domain, it also may contain copyrighted materials as noted in the text. Permission to reproduce copyrighted items must be secured from the copyright owner.

Suggested citation:

Molina-Rivera, W.L., Estimated water use in Puerto Rico, 2010: U.S. Geological Survey Open-File Report 2014-1117, 35 p., http://dx.doi.org/10.3133/ofr20141117.

ISSN 2331-1258 (online) 


\section{Contents}

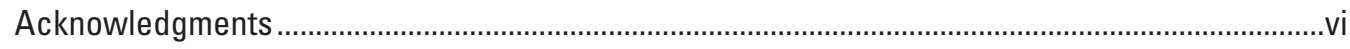

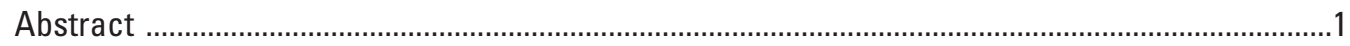

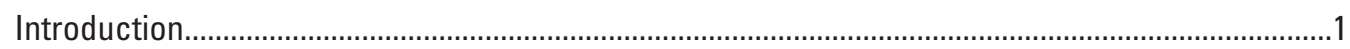

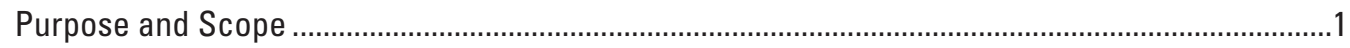

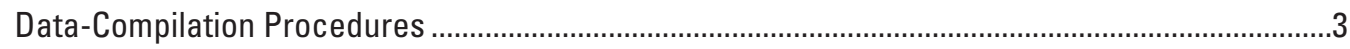

Public-Supply Water Withdrawals, Deliveries and Population Served.....................................

Domestic Deliveries from Public-Supply Water ……………...................................................

Domestic Self-Supplied Water Use ....................................................................................

Industrial Self-Supplied Withdrawals ..................................................................................

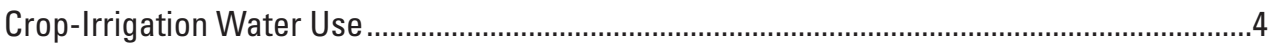

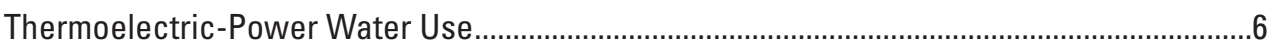

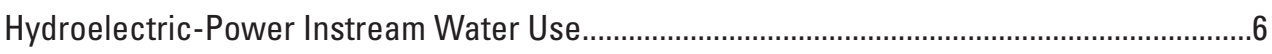

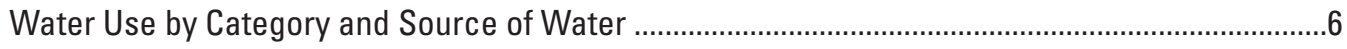

Public-Supply Water Withdrawals and Deliveries..................................................................

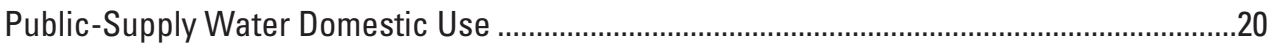

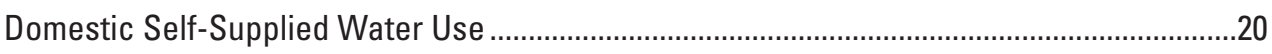

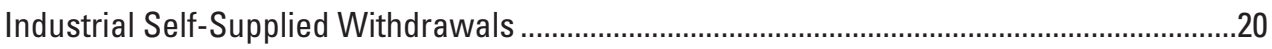

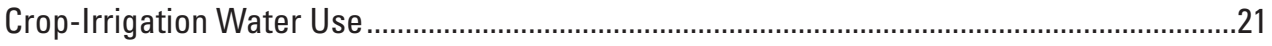

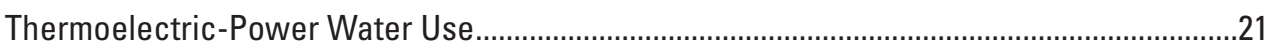

Hydroelectric-Power Instream Water Use.........................................................................21

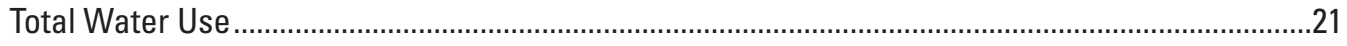

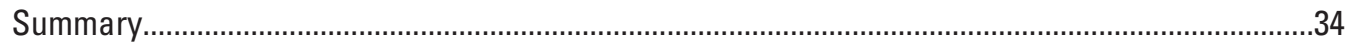

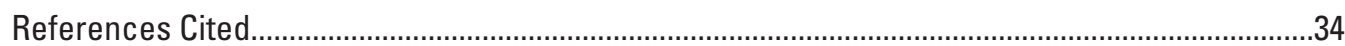

\section{Figures}

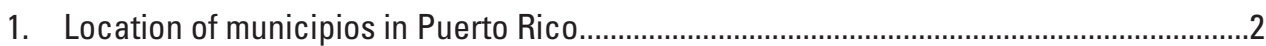

2. Location of the Puerto Rico Electric Power Authority Irrigation Districts in Puerto Rico, 2010. See figure 1 for the names of the municipios .......................................

3. Location of major irrigated agricultural areas in Puerto Rico, from Rincón to mid Quebradillas, from Cabo Rojo to mid Juana Diaz and from mid

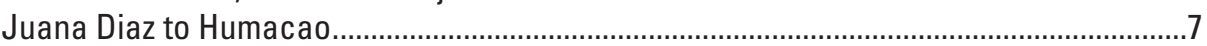

4. Location of thermoelectric powerplants in Puerto Rico, 2010 ........................................

5. Location of hydroelectric powerplants in Puerto Rico, 2010 ...........................................9

6. Population served by public-supply water systems by municipios

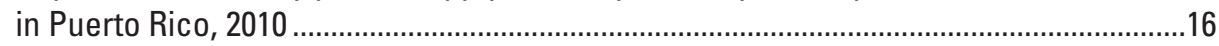

7. Public-supply water deliveries by municipios in Puerto Rico, 2010 ..................................17

8. Water deliveries among the North Coast Aqueduct interconnections in

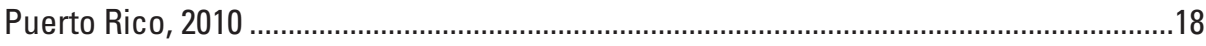

9. Location of municipios interconnectied to the North Coast Aqueduct and public-supply water deliveries, in million gallons per day, 2010 ...............................19

10. Domestic water use per capita coefficients by municipios in Puerto Rico, 2010. 


\section{Tables}

1. Estimated population served and public-supply water withdrawals in Puerto Rico by source and municipio, 2010.

2. Estimated deliveries from public-supply water systems to domestic use, population served and domestic per capita use in Puerto Rico by source and municipio, 2010

3. Estimated domestic self-supplied withdrawals from groundwater sources, population served and domestic per capita use in Puerto Rico by municipio, 2010

4. Industrial self-supplied withdrawals from groundwater sources in Puerto Rico by municipio, 2010.

5. Estimated irrigation water use, cultivated and irrigated acres and irrigation methods in Puerto Rico by source and municipio, 2010.

6. Withdrawals and deliveries from public-supply water by public thermoelectric power plants in Puerto Rico by source and municipio, 2010.

7. Water use and power generated by hydroelectric power plants in Puerto Rico by municipio, 2010

8. Summary of total water use in Puerto Rico, 2010.

9. Total freshwater withdrawals in Puerto Rico by offstream water-use categories and municipios, 2010.

Appendix Table (Excel file available for download at $h t t p: / / p u b s . u s g s . g o v / o f / 2014 / 1117 /$

A1. Estimated public-supply water deliveries, population served and per capita deliveries in Puerto Rico by ward and municipio, 2010. Separate Excel file 


\section{Conversion Factors}

\begin{tabular}{lcl}
\multicolumn{1}{l}{ Inch/Pound to SI } & & \\
\hline \multicolumn{1}{c}{ Multiply } & By & \multicolumn{1}{c}{ To obtain } \\
\hline acre & Area & \\
\hline & 4,047 & square meter $\left(\mathrm{m}^{2}\right)$ \\
\hline gallon (gal) & Volume & \\
acre-foot (acre-ft) & 3.785 & liter $(\mathrm{L})$ \\
\hline & $1,233.489$ & cubic meter $\left(\mathrm{m}^{3}\right)$ \\
\hline acre-foot per year (acre-ft/yr) & Flow rate & \\
gallon per day (gal/d) & 0.001233 & cubic hectometer per year $\left(\mathrm{hm}^{3} / \mathrm{yr}\right)$ \\
million gallons per day $(\mathrm{Mgal} / \mathrm{d})$ & 0.003785 & cubic meter per day $\left(\mathrm{m}^{3} / \mathrm{d}\right)$ \\
\hline
\end{tabular}

Temperature in degrees Celsius $\left({ }^{\circ} \mathrm{C}\right)$ may be converted to degrees Fahrenheit $\left({ }^{\circ} \mathrm{F}\right)$ as follows:

${ }^{\circ} \mathrm{F}=\left(1.8 x^{\circ} \mathrm{C}\right)+32$

Temperature in degrees Fahrenheit $\left({ }^{\circ} \mathrm{F}\right)$ may be converted to degrees Celsius $\left({ }^{\circ} \mathrm{C}\right)$ as follows:

${ }^{\circ} \mathrm{C}=\left({ }^{\circ} \mathrm{F}-32\right) / 1.8$

Vertical coordinate information is referenced to local mean sea level.

Horizontal coordinate information is referenced to the Puerto Rico Datum, 1940 adjustment.

\section{Abbreviations}

$\begin{array}{ll}\text { gWh } & \text { gigawatt-hour } \\ \text { NCA } & \text { North Coast Aqueduct } \\ \text { PRASA } & \text { Puerto Rico Aqueduct and Sewer Authority } \\ \text { PRDNER } & \text { Puerto Rico Department of Natural and Environmental Resources } \\ \text { PRDOH } & \text { Puerto Rico Department of Health } \\ \text { PREPA } & \text { Puerto Rico Electric Power Authority } \\ \text { PREOB } & \text { Puerto Rico Environmental Quality Board } \\ \text { PRLA } & \text { Puerto Rico Land Authority } \\ \text { USGS } & \text { U.S. Geological Survey }\end{array}$




\section{Acknowledgments}

The authors gratefully acknowledge the following Commonwealth agencies for their cooperation in making the water-use data available: the Puerto Rico Aqueduct and Sewer Authority regional and area offices, Permit and Franchise Division of Puerto Rico Department of Natural and Environmental Resources, the Puerto Rico Environmental Quality Board, the Puerto Rico Electric Power Authority, the Puerto Rico Department of Health, and the Puerto Rico Land Authority. 


\title{
Estimated Water Use in Puerto Rico, 2010
}

\author{
By Wanda L. Molina-Rivera
}

\section{Abstract}

Water-use data were aggregated for the 78 municipios of the Commonwealth of Puerto Rico for 2010. Five major offstream categories were considered: public-supply water withdrawals and deliveries, domestic and industrial self-supplied water use, crop-irrigation water use, and thermoelectric-power freshwater use. One instream wateruse category also was compiled: power-generation instream water use (thermoelectric saline withdrawals and hydroelectric power). Freshwater withdrawals for offstream use from surface-water [606 million gallons per day (Mgal/d)] and groundwater $(118 \mathrm{Mgal} / \mathrm{d})$ sources in Puerto Rico were estimated at 724 million gallons per day. The largest amount of freshwater withdrawn was by public-supply water facilities estimated at $677 \mathrm{Mgal} / \mathrm{d}$. Public-supply domestic water use was estimated at $206 \mathrm{Mgal} / \mathrm{d}$. Fresh groundwater withdrawals by domestic self-supplied users were estimated at $2.41 \mathrm{Mgal} / \mathrm{d}$. Industrial self-supplied withdrawals were estimated at $4.30 \mathrm{Mgal} / \mathrm{d}$. Withdrawals for crop irrigation purposes were estimated at $38.2 \mathrm{Mgal} / \mathrm{d}$, or approximately 5 percent of all offstream freshwater withdrawals. Instream freshwater withdrawals by hydroelectric facilities were estimated at $556 \mathrm{Mgal} / \mathrm{d}$ and saline instream surface-water withdrawals for cooling purposes by thermoelectric-power facilities was estimated at 2,262 Mgal/d.

\section{Introduction}

The National Water-Use Information Program of the U.S. Geological Survey (USGS) is a cooperative program designed to compile, store, and disseminate water-use information locally and nationwide. Since 1950, the USGS has compiled data at 5-year intervals on amounts of water used in homes, businesses, and on farms in the United States, and has described how that use has changed with time. The program was implemented in Puerto Rico in 1980 to provide data for the management of the Commonwealth's water resources. Water-use data reports by "municipios" were published for 1980-82 (Torres and Avilés, 1986), 1986-87 (Molina and Dopazo, 1995), for 1988-89
(Dopazo and Molina, 1995), for 1995, 2000 (Molina, 1998, 2005) and for 2005 (Molina and Gómez, 2008). Water-resources planners and managers must have information regarding the amount of water used, and where and how it is used, to adequately assess many of the critical water problems facing Puerto Rico.

The USGS maintains cooperative agreements with the Puerto Rico Aqueduct and Sewer Authority (PRASA), the Puerto Rico Department of Natural and Environmental Resources (PRDNER), and the Puerto Rico Environmental Quality Board (PREQB). A compilation of water-use data for major use categories is an important requirement to assist water-resources managers and planners in Puerto Rico.

\section{Purpose and Scope}

The purpose of this report is to document wateruse data estimates in Puerto Rico for 2010. Estimated water use was determined for the following categories: (1) surface-water and groundwater withdrawals and their deliveries by public-supply facilities, (2) domestic use from public-supply water and self-supplied (3) groundwater withdrawals by industrial self-supplied users, (4) surfacewater and groundwater withdrawals for crop irrigation, and (5) groundwater withdrawals and public-supply deliveries for thermoelectric-power use. In addition, instream wateruse and saline withdrawals were estimated for hydroelectricpower generation and for cooling purposes at thermoelectric powerplants.

Estimated water use was aggregated by municipios and sources of water for most of the water-use categories presented in this report. Public-supply water deliveries were categorized by ward ("barrios"), estimating the population served by individual public-supply water system. The location and geographic distribution of the 78 municipios of Puerto Rico are shown in figure 1. 


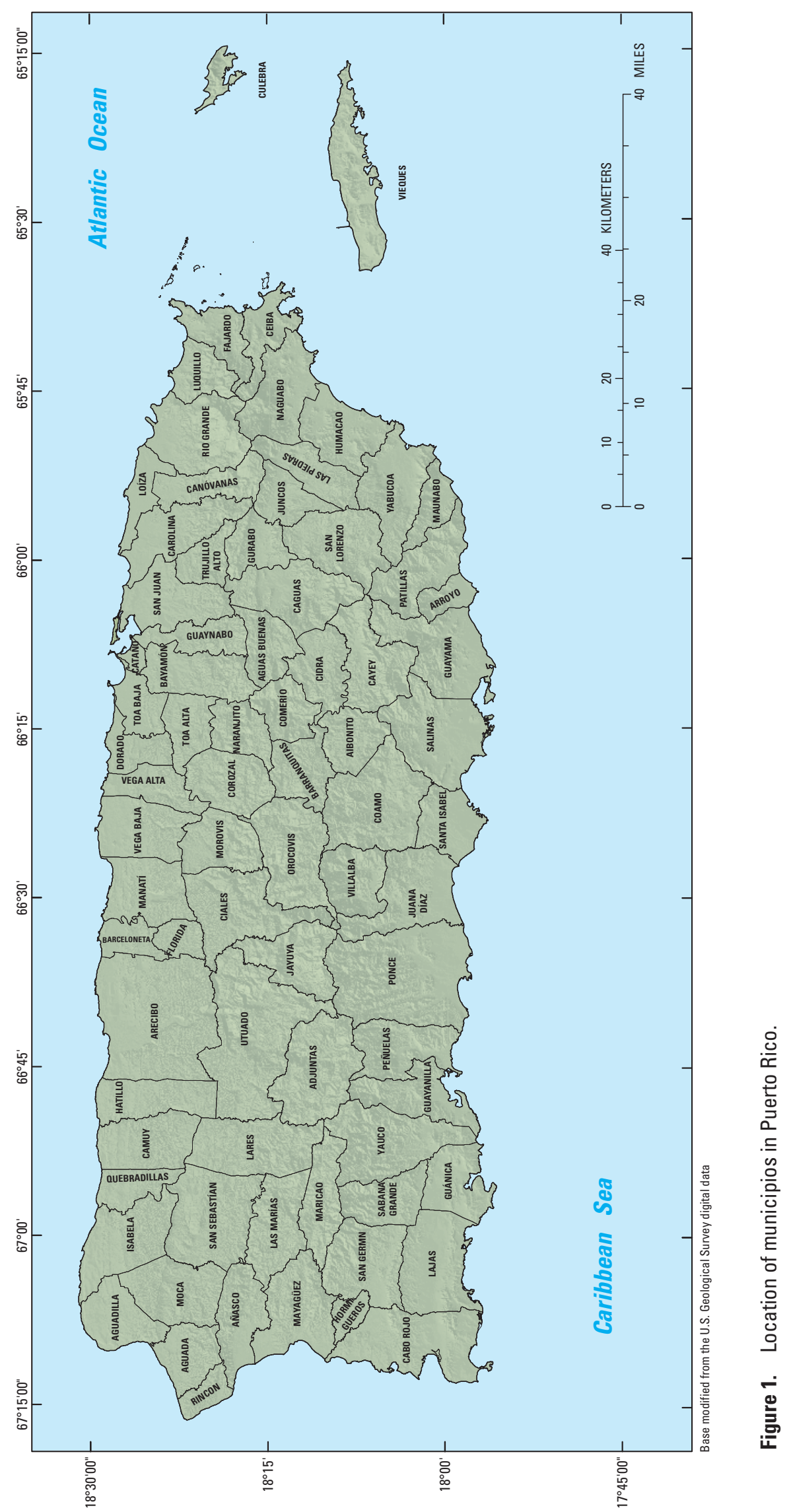




\section{Data-Compilation Procedures}

Water-use data for major offstream categories were compiled for: public-supply water (surface-water and groundwater facilities) by municipios and by wards; domestic and industrial self-supplied use; crop irrigation, thermoelectric and hydroelectric-power water-use categories by source of water and municipios. The sources of data and the methods used to compile water use differ for each category and are described in the following sections.

\section{Public-Supply Water Withdrawals, Deliveries and Population Served}

In this report, public-supply water withdrawal is water withdrawn by public and private suppliers that furnish water for at least 25 people or have a minimum of 15 service connections (U.S. Environmental Protection Agency, 2012). Data documenting freshwater withdrawals from PRASA surface-water facilities and wells, by municipio, during 2010 were obtained from the PRASA (2010). Data documenting withdrawals from non-PRASA systems were obtained from the PRDOH (2010). Public-supply water withdrawals were compiled at a municipal level in which the withdrawals take place, although the water subsequently may be distributed and used elsewhere. Public-supply water withdrawal data were aggregated for the 78 municipios of Puerto Rico (fig. 1) and by sources of water and were sub-divided as PRASA or non-PRASA systems. The non-PRASA systems refer to community water systems that supply water to the same population year-round (U.S. Environmental Protection Agency, 2012).

Public-supply water deliveries were aggregated by wards based on the population served by the public-supply water system (PRASA and non-PRASA) in the area. Public-supply water deliveries were estimated for wards that are served as follow: exclusively from water treatment plants, exclusively from groundwater wells and for surface-water systems that are augmented by groundwater.

The population served refers to the resident population within a municipio receiving water from a public-supply water system on a year-round basis and excludes seasonal residents. In this report, the population served was estimated by the individual public-supply water system in the municipio where the delivery of water took place, which is not necessarily the municipio where the withdrawal took place. The combined total of all users of public-supply water served by the PRASA, non-PRASA, and domestic self-supplied users was considered in this report to equal the 2010 total population estimate obtained by the U.S. Census Bureau (2011). Public-supply water per capita use was obtained by dividing the average daily total public-supply water use by the population served.

\section{Domestic Deliveries from Public-Supply Water}

Domestic delivery represents water distributed by a public-supply facility to residential customers for domestic purposes, both indoor (drinking, washing, flushing) and outdoor (lawn watering, car washing, replenishing swimming pools). Public-supply domestic water delivery data were estimated from a report prepared by PRASA (Puerto Rico Aqueduct and Sewer Authority, 2009-2010, "PRASA Water Distribution Systems Assessment Fact Sheet"). Domestic water deliveries data for PRASA and non-PRASA systems were estimated applying a domestic per capita use coefficient to the population served. The aforementioned PRASA reports, prepared by each public-supply water system, contain summarized information on residential average consumption in gallons per day for 2010 .

A domestic per capita use coefficient was calculated for each public-supply water system in Puerto Rico. Residential use varies from household to household; however households served by the same public-supply water system often have a common pattern of use affected by factors such as water cost rates, water conservation patterns, customer affluence, climate and topography. As a result, a public-supply domestic per capita water use coefficient can be determined for a specific system. Therefore, the coefficient for one system may or may not be valid for all systems within Puerto Rico.

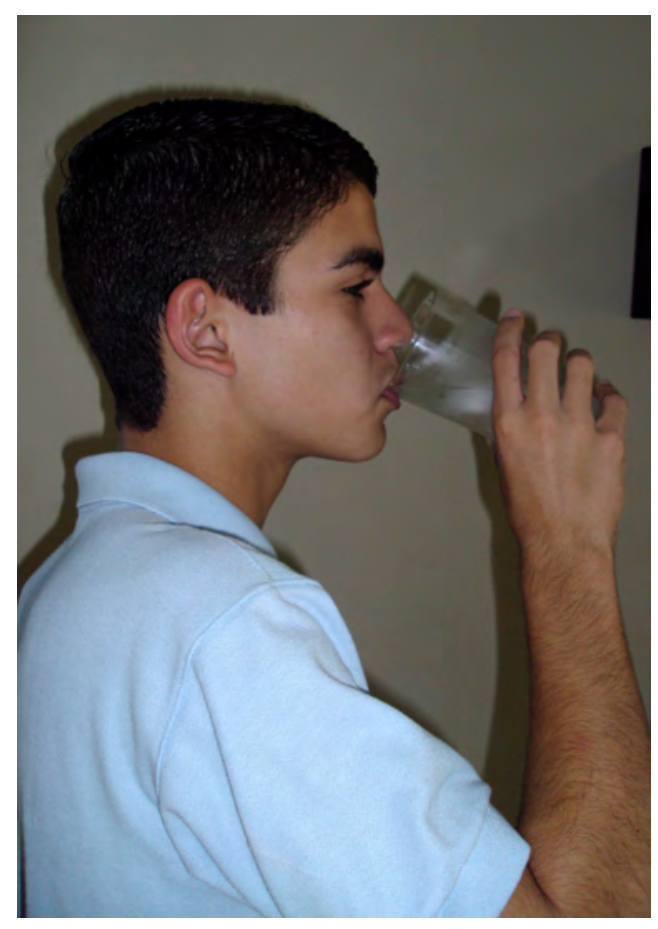

Example of consumptive use, photograph by Wanda L. Molina, January 30, 2009. 


\section{Domestic Self-Supplied Water Use}

Domestic self-supplied water use refers to water used by individual households that are not served by public-supply water systems - PRASA and non-PRASA. Data on freshwater withdrawals and population served were not available for the domestic self-supplied water-use estimates. Self-supplied domestic withdrawals were estimated by multiplying the self-supplied population by a public-supply water domestic per capita use coefficient. The self-supplied population is calculated by subtracting total resident population served by public-supply water systems in a municipio from the total 2010 Census of Population (U.S. Census Bureau, 2010) in the municipio.

In 2000, in the United States, the water source for about 98 percent of self-supplied domestic withdrawals was groundwater (Hutson and others, 2004). In Puerto Rico, it is assumed that the domestic self-supplied withdrawals come mainly from groundwater sources.

\section{Industrial Self-Supplied Withdrawals}

Industrial self-supplied withdrawals refer to water used for industrial purposes in such industries as pharmaceutical, chemical and allied products, food processing, and petroleum refining. The withdrawal data estimates included are limited to industrial self-supplied groundwater withdrawals and were provided by the PRDNER Permits and Water Franchise Division and from individual industries.

In Puerto Rico, most of the self-supplied industries are located along the north coast of the island and can be grouped in the North American Industry Classification System Code (NAICS) code number 325412 (U.S. Bureau of Census, 2012). The NAICS code 325412 refers to pharmaceutical preparation manufacturing where self-supplied industrial withdrawals were greatest due to the need of large amounts of water for fabricating and processing.

\section{Crop-Irrigation Water Use}

Crop-irrigation water use is defined as water applied to the land to assist in the growing of crops, nursery plants, and pastures. Water applied to golf courses and parks was not included in this category. Surface-water withdrawals for crop-irrigation purposes were estimated for agricultural areas served by four irrigation districts managed by the PREPA. The four irrigation districts are the Guayama and Juana Díaz Irrigation Districts in the south; the Valle de Lajas Irrigation District, in the southwest, and the Isabela Irrigation District in northwestern Puerto Rico (fig. 2).

The Guayama Irrigation District (fig. 2) withdraws water from the Lago Patillas and the Lago Melania reservoirs, the Río Guamaní, and from an intrabasin transfer of water from Lago Carite to the Río Guamaní. These streams and lakes transfer water to agricultural lands in the municipios of Arroyo, Guayama, Patillas and Salinas (fig. 1). In 2010, water conveyed by the Guayama Irrigation District was also the source of publicsupply water to three PRASA water treatment plants (WTP) that delivered water to the municipios of Arroyo, Guayama, Maunabo, Patillas and Salinas (fig. 1). The Guayama Urbano WTP is supplied from the Patillas irrigation canal; the Farallón WTP from Lago Carite; and, the Patillas Urbano WTP from Lago Patillas. Also, the Guayama Irrigation District delivered fresh surface water to a private thermoelectric company in the area, not included in this report.

The Juana Díaz Irrigation District (fig. 2) withdraws water exclusively from the Lago Guayabal reservoir in the municipio of Villalba and conveys the water to agricultural lands in the municipios of Juana Díaz, Santa Isabel, and the part of Salinas (fig. 1) to the west of Río Nigua. In 2010, water conveyed by the Juana Díaz Irrigation District was also the source of publicsupply water for two PRASA WTPs in the municipios of Villalba (fig. 1), these are as follow: the Villalba WTP at Rio Jacaguas and the La Julita WTP at Lago Guineo.

The Valle de Lajas Irrigation District (fig. 2) withdraws water from the Lago Loco and Lago Luchetti reservoirs of the municipio of Yauco and conveys the water to agricultural lands in the municipios of Cabo Rojo, Guánica, Lajas, Sabana Grande, and Yauco (fig. 1). Water diversion from Lago Loco and Lago Luchetti to the Valle de Lajas Irrigation District provided the surface water withdrawn by the PRASA to WTPs in the municipios of Sabana Grande, Lajas, and Cabo Rojo (fig. 1), these WTPs are as follow: Máginas WTP, Lajas WTP and Betances WTP.

The Isabela Irrigation District (fig. 2) withdraws water exclusively from Lago Guajataca reservoir, which is located in the municipios of Isabela and San Sebastián. The irrigation district conveys the water to agricultural lands in the municipios of Aguadilla, Isabela, and Moca (fig. 1). Diversion from Lago Guajataca, which is conveyed through the Canal de Moca and the Canal de Aguadilla, provided the surface water withdrawn by Aguadilla Nueva and Ramey PRASA WTPs. These public-supply water treatment plants serve the population of the municipos of Aguada, Aguadilla, Moca and Rincón (fig. 1).

Estimates of surface-water irrigation delivered to farms at irrigation districts were provided monthly by the PREPA. To assist in the objective of accurately measuring irrigation canal withdrawals, the following USGS streamflow stations were operated during 2010: USGS station 50093053 Canal de Patillas at Forebay; USGS station 50095000 Canal de Guamaní Oeste; USGS station 50039995 Lago Carite; USGS station 50111310 West Forebay at Lago Guayabal; USGS station 50111305 East Forebay at Lago Guayabal; and USGS station 50011000 Canal de Diversion Lago Guajataca. Streamflow data for Puerto Rico are available from the USGS Caribbean Water Science Center Web site at http://wdr.water.usgs.gov/.

Groundwater withdrawals for crop-irrigation purposes were estimated in the municipios along the irrigation districts and also at Coamo, Guayanilla, Maunabo, Peñuelas, Ponce and Yabucoa. Groundwater withdrawals were estimated as the difference of the total irrigation water use and the amount of surface water diverted from irrigation canals to the municipio. 


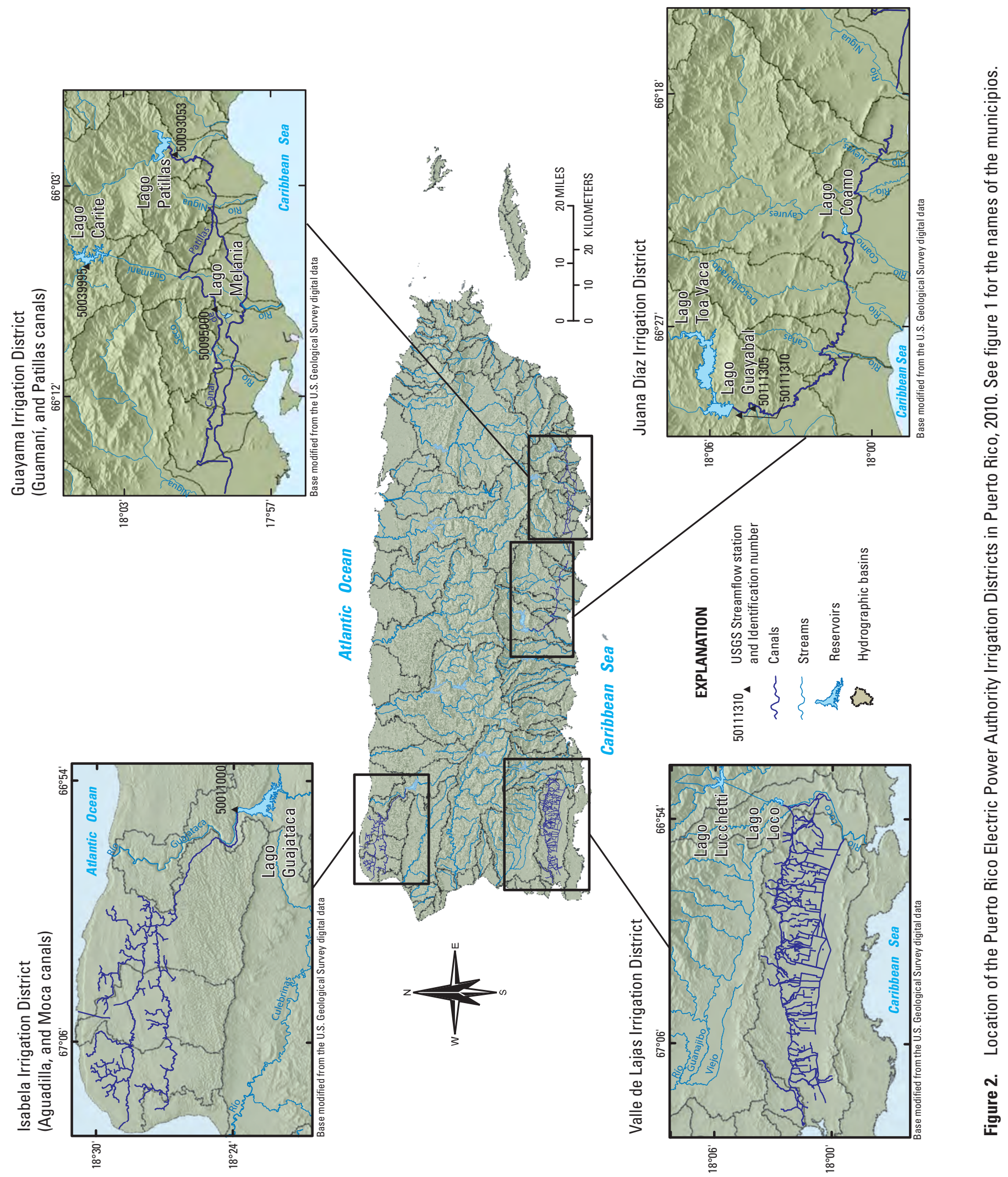


Irrigation application rates were estimated by adjusting the 2005 application rates (Molina and Gómez, 2008) based on the changes in rainfall in the two climatic divisions of Puerto Rico where most of the agricultural lands are located. The two climatic divisions used were the south coast and north coast. The percent differences in annual rainfall from 2005 to 2010 were +9.2 percent in the south coast and +6.9 percent in the north coast (U.S. Department of Commerce, 2010). The application rates were multiplied by the irrigated acres at each municipio to determine the total irrigation water use. Groundwater withdrawals for irrigation were estimated as the difference of the total irrigation water used and the applied surface water reported.

The number of acres that were irrigated were obtained from the delineation of acreage of land cultivated in municipios within the irrigation districts, using aerial imagery collected in 2010 by the Puerto Rico Planning Board, 2010 (fig. 3).

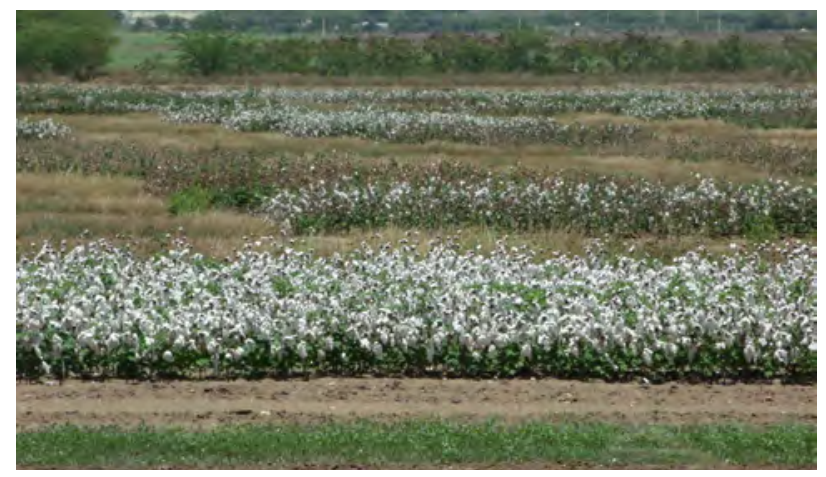

Cotton crops in south coast of Puerto Rico, photograph by Marcos Quiñones, April 13, 2012.

\section{Thermoelectric-Power Water Use}

The thermoelectric-power category includes water that is used to generate electricity by using fossil fuel. In Puerto Rico, all of the saline water withdrawals are made up entirely of seawater used for once-through cooling purposes. When freshwater is used at thermoelectric powerplants it is self-supplied or is delivered by a water supplier through a distribution system and is used mostly for boiler feed and domestic use within the facility. In 2010, Puerto Rico had six active thermoelectric powerplants, four operated by the PREPA (fig. 4) and two by private companies that were not included in this report. The estimates of water withdrawals by public thermoelectric power plants were provided by the PREPA and the Franchise and Permit Division of the PRDNER.

\section{Hydroelectric-Power Instream Water Use}

Water used for hydroelectric-power generation is classified as instream use and refers to water that is used to generate electricity at powerplants, by using turbine generators that are driven by falling water. During 2010, there were nine active hydroelectric powerplants throughout Puerto Rico (fig. 5).

\section{Water Use by Category and Source of Water}

Water-use data are divided into offstream and instream uses. Offstream use is defined as water withdrawn or diverted from surface-water or groundwater sources and conveyed to the place of use. Offstream water-use categories considered in this report are as follows: public-supply water withdrawals, domestic and industrial self-supplied groundwater withdrawals, crop irrigation water use, and thermoelectric-power freshwater use. Offstream freshwater was estimated at 724 million gallons per day (Mgal/d) in Puerto Rico during 2010. The largest offstream use was for public-supply water withdrawals, which accounted for $677 \mathrm{Mgal} / \mathrm{d}$ (93 percent) of the total withdrawals; $38.2 \mathrm{Mgal} / \mathrm{d}$ (5 percent) of all offstream freshwater withdrawals was used for crop-irrigation purposes. Fresh groundwater withdrawals for domestic self-supplied water use were estimated to be $2.41 \mathrm{Mgal} / \mathrm{d}$, and industrial self-supplied groundwater use was estimated to be $4.30 \mathrm{Mgal} / \mathrm{d}$. Freshwater withdrawals for thermoelectric powerplants accounted for $1.67 \mathrm{Mgal} / \mathrm{d}$ in 2010 .

Instream use is defined as water that is used, but not withdrawn, from a surface-water source for such purposes as hydroelectric power generation or saline withdrawals in thermoelectric plants. An estimated 2,817 Mgal/d was used under the category of instream use throughout Puerto Rico during 2010 for hydroelectric and thermoelectric-power generation.

\section{Public-Supply Water Withdrawals and Deliveries}

During 2010, public-supply water distributed by the PRASA was provided by 127 active public water treatment plants and 246 public-supply wells. Non-PRASA accounted for 108 surfacewater facilities and 140 domestic wells serving communities with 15 or more connections. PRASA and non-PRASA systems withdrew $677 \mathrm{Mgal} / \mathrm{d}$ (590 Mgal/d from surface-water and 87 $\mathrm{Mgal} / \mathrm{d}$ from groundwater facilities) (table 1) and delivered $663 \mathrm{Mgal} / \mathrm{d}$ (656 Mgal/d from PRASA and $7 \mathrm{Mgal} / \mathrm{d}$ from non-PRASA systems) (appendix 1). Of the total population in Puerto Rico for 2010 (3,725.789 thousand residents), 96 percent $(3,586.165$ thousand residents) were estimated to be served by a public-supply water system belonging to the PRASA. The nonPRASA systems served approximately 3 percent of the population (101.627 thousand residents) (table 1), and 1 percent of the population (37.997 thousand residents) was served by domestic self-supplied wells.

Public-supply water deliveries to the municipio of San Juan were estimated as $83.8 \mathrm{Mgal} / \mathrm{d}$ exclusively from surface-water facilities serving a population of 395.326 thousand residents (figs. 6 and 7). The PRASA metropolitan area systems also include the following municipios: Aguas Buenas, Bayamón, Caguas, Canóvanas, Carolina, Guaynabo, Gurabo, Juncos, Loíza, Naranjito Toa Alta, Toa Baja, and Trujillo Alto. Figure 7 also shows a distribution of the public-supply water deliveries among Puerto Rico. 
The North Coast Aqueduct (NCA), commonly referred to as the "Superaqueduct", a major public-supply facility, which entered into operation about September 2000, transfers water from the Río Grande de Arecibo Basin to the San Juan Metropolitan area through seven interconnections along the distribution system:
Miraflores, Sabana Hoyos, Barceloneta, Manatí, Vega Baja, Vega Alta/Dorado, and Bayamón. Water deliveries among the NCA interconnections are shown in figure 8. In 2010, the NCA delivered $101 \mathrm{Mgal} / \mathrm{d}$ to the 17 municipios shown on figure 9 .
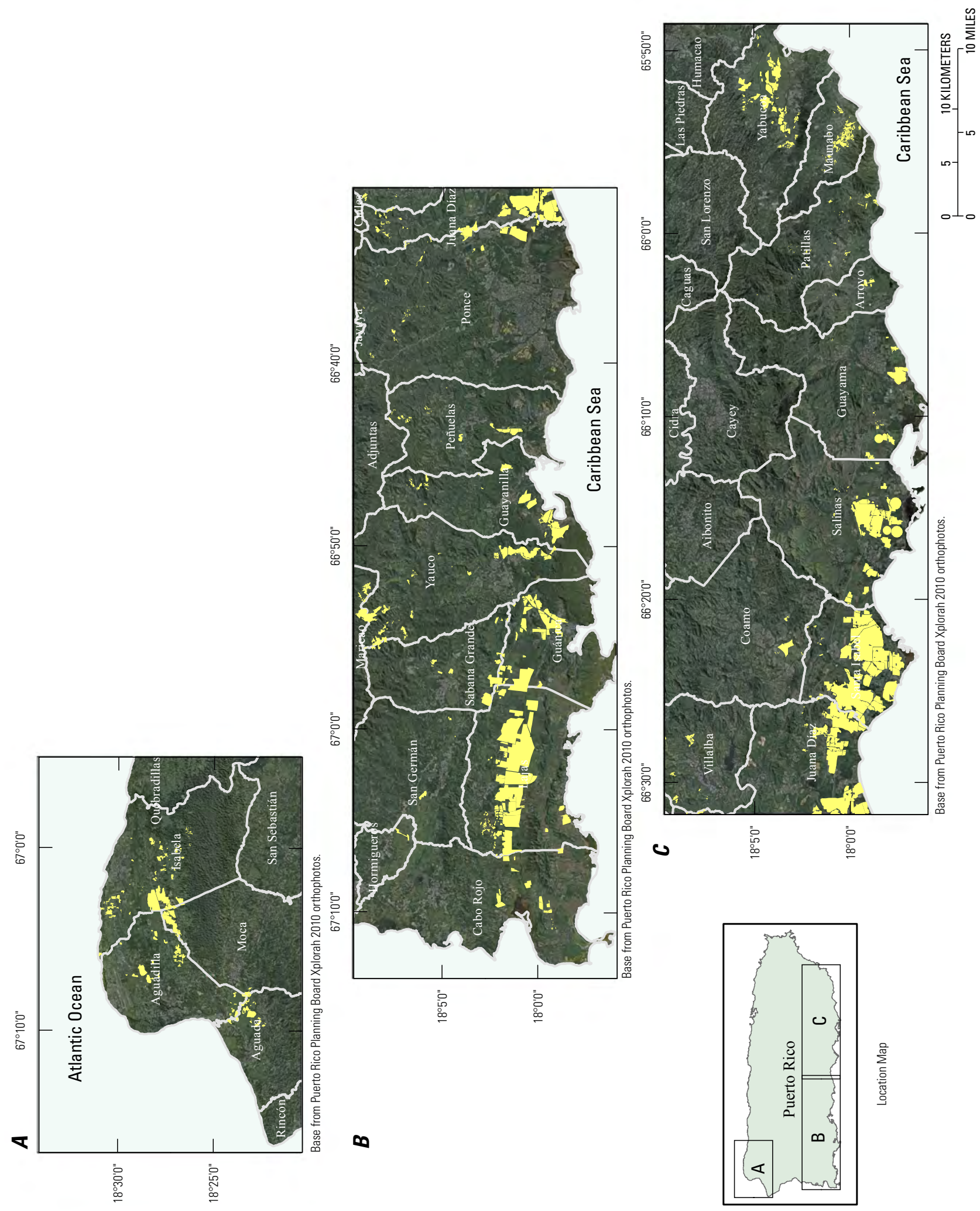

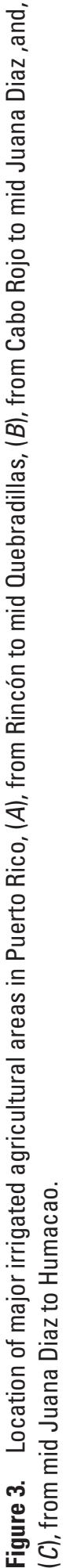




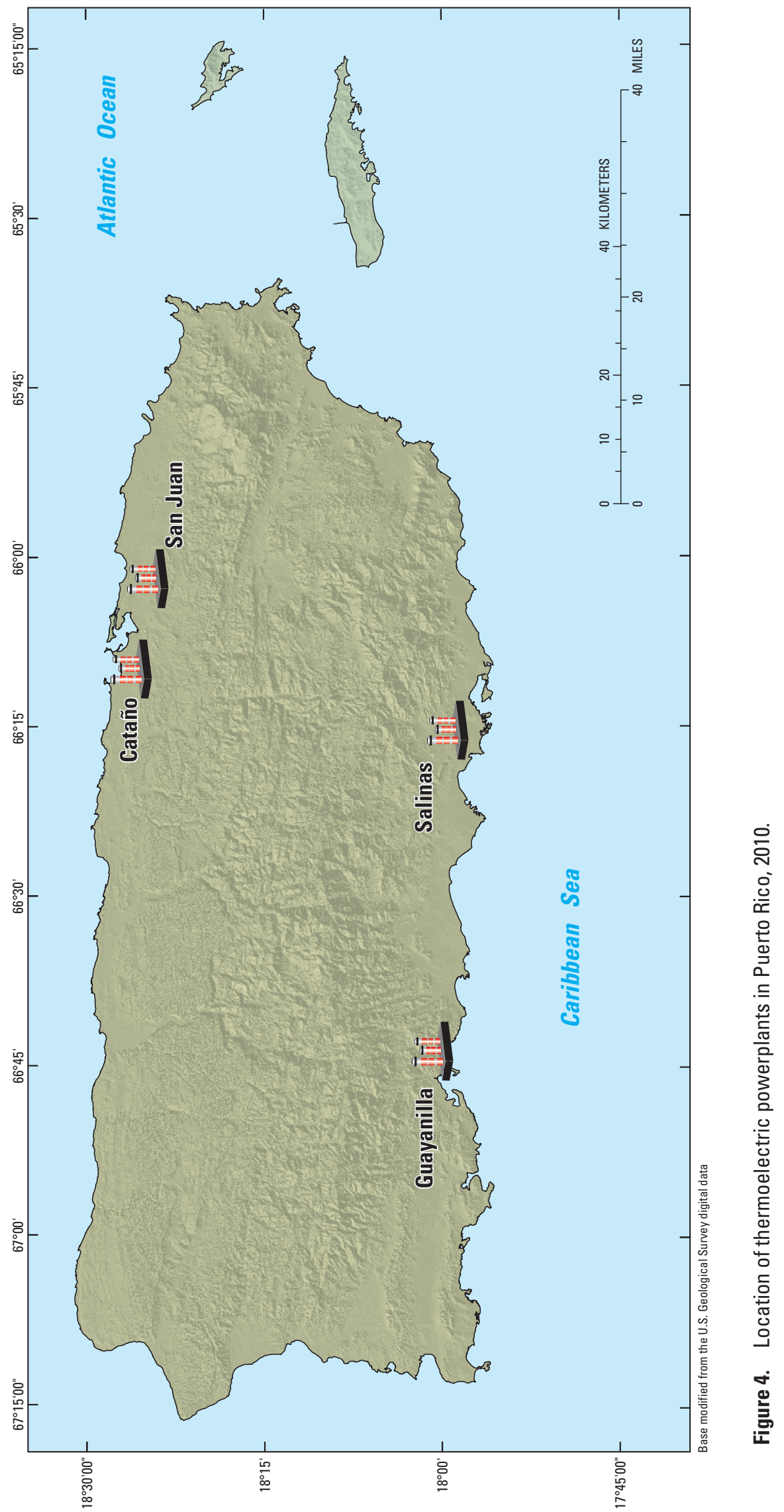




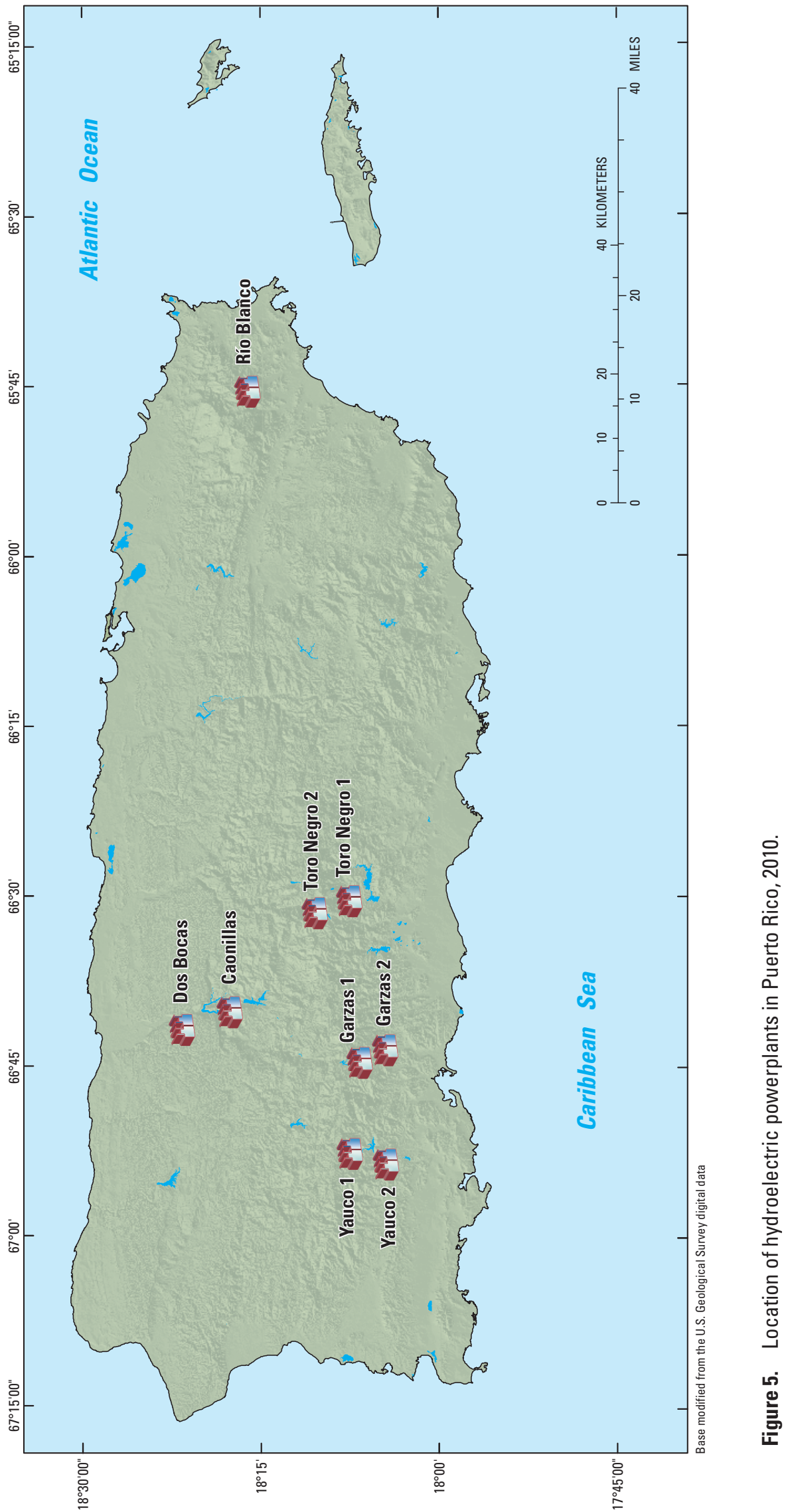


Table 1. Estimated population served and public-supply water withdrawals in Puerto Rico by source and municipio, 2010.

[Source: U.S. Geological Survey, Caribbean Water Science Center; withdrawals are accounted in the municipios where the intakes are located; PRASA, Puerto Rico Aqueduct and Sewer Authority; sw, surface water; gw, groundwater; Mgal/d, million gallons per day; some municipios are served exclusively from surface-water systems, exclusively from groundwater wells, and for surface-water systems that are augmented by groundwater]

\begin{tabular}{|c|c|c|c|c|c|c|c|}
\hline \multirow[b]{2}{*}{ Municipio } & \multirow[b]{2}{*}{$\begin{array}{l}2010 \text { Census } \\
\text { of population, } \\
\text { in thousands }\end{array}$} & \multicolumn{6}{|c|}{ PRASA } \\
\hline & & $\begin{array}{l}\text { Population } \\
\text { served by GW, } \\
\text { in thousands }\end{array}$ & $\begin{array}{c}\text { Population } \\
\text { served by SW, } \\
\text { in thousands }\end{array}$ & $\begin{array}{l}\text { Total popula- } \\
\text { tion served, in } \\
\text { thousands }\end{array}$ & $\begin{array}{c}\text { Groundwater } \\
\text { withdrawals, } \\
\text { in Mgal/d }\end{array}$ & $\begin{array}{l}\text { Surface water } \\
\text { withdrawals, } \\
\text { in Mgal/d }\end{array}$ & $\begin{array}{l}\text { Total withdrawals, } \\
\text { in Mgal/d }\end{array}$ \\
\hline Puerto Rico & $3,725.789$ & 296.188 & $3,289.977$ & $3,586.165$ & 83.00 & 587.17 & 670.17 \\
\hline Adjuntas & 19.483 & 1.222 & 16.011 & 17.233 & 0.07 & 1.01 & 1.08 \\
\hline Aguada & 41.959 & 0.000 & 38.319 & 38.319 & 0.81 & 0.00 & 0.81 \\
\hline Aguadilla & 60.949 & 0.000 & 58.915 & 58.915 & 0.00 & 27.79 & 27.79 \\
\hline Aguas Buenas & 28.659 & 0.000 & 23.179 & 23.179 & 0.28 & 21.07 & 21.35 \\
\hline Aibonito & 25.900 & 0.302 & 20.879 & 21.181 & 0.70 & 2.98 & 3.68 \\
\hline Añasco & 29.261 & 0.000 & 27.341 & 27.341 & 0.43 & 2.19 & 2.62 \\
\hline Arecibo & 96.440 & 8.553 & 83.296 & 91.849 & 14.92 & 103.64 & 118.56 \\
\hline Arroyo & 19.575 & 14.821 & 4.754 & 19.575 & 1.76 & 0.00 & 1.76 \\
\hline Barceloneta & 24.816 & 6.424 & 18.392 & 24.816 & 1.68 & 0.00 & 1.68 \\
\hline Barranquitas & 30.318 & 0.000 & 23.833 & 23.833 & 1.04 & 2.20 & 3.24 \\
\hline Bayamón & 208.116 & 0.000 & 208.116 & 208.116 & 0.00 & 0.19 & 0.19 \\
\hline Cabo Rojo & 50.917 & 0.000 & 50.917 & 50.917 & 4.40 & 1.81 & 6.21 \\
\hline Caguas & 142.893 & 0.000 & 133.394 & 133.394 & 0.05 & 9.01 & 9.06 \\
\hline Camuy & 35.159 & 2.162 & 32.997 & 35.159 & 0.46 & 1.54 & 2.00 \\
\hline Canóvanas & 47.648 & 0.000 & 47.648 & 47.648 & 0.00 & 6.78 & 6.78 \\
\hline Carolina & 176.762 & 0.000 & 175.937 & 175.937 & 0.00 & 0.00 & 0.00 \\
\hline Cataño & 28.140 & 0.000 & 28.140 & 28.140 & 0.00 & 0.00 & 0.00 \\
\hline Cayey & 48.119 & 0.278 & 47.121 & 47.399 & 0.00 & 2.42 & 2.42 \\
\hline Ceiba & 13.631 & 0.000 & 13.631 & 13.631 & 0.00 & 0.00 & 0.00 \\
\hline Ciales & 18.782 & 0.743 & 17.651 & 18.394 & 0.00 & 2.57 & 2.57 \\
\hline Cidra & 43.480 & 0.000 & 37.435 & 37.435 & 0.14 & 5.69 & 5.83 \\
\hline Coamo & 40.512 & 28.558 & 10.414 & 38.972 & 0.09 & 0.84 & 0.93 \\
\hline Comerio & 20.778 & 0.000 & 18.277 & 18.277 & 0.43 & 2.95 & 3.38 \\
\hline Corozal & 37.142 & 0.000 & 31.009 & 31.009 & 0.00 & 3.62 & 3.62 \\
\hline Culebra & 1.818 & 0.000 & 1.818 & 1.818 & 0.00 & 0.00 & 0.00 \\
\hline Dorado & 38.165 & 15.178 & 22.987 & 38.165 & 3.89 & 0.00 & 3.89 \\
\hline Fajardo & 36.993 & 0.000 & 36.833 & 36.833 & 0.00 & 12.12 & 12.12 \\
\hline Florida & 12.680 & 8.454 & 4.226 & 12.680 & 2.20 & 0.00 & 2.20 \\
\hline Guánica & 19.427 & 19.427 & 0.000 & 19.427 & 3.21 & 0.00 & 3.21 \\
\hline Guayama & 45.362 & 4.775 & 40.312 & 45.087 & 0.99 & 12.74 & 13.73 \\
\hline Guayanilla & 21.581 & 18.190 & 3.271 & 21.461 & 2.49 & 0.22 & 2.71 \\
\hline Guaynabo & 97.924 & 0.000 & 95.133 & 95.133 & 0.00 & 8.03 & 8.03 \\
\hline Gurabo & 45.369 & 0.000 & 43.211 & 43.211 & 0.00 & 2.97 & 2.97 \\
\hline Hatillo & 41.953 & 2.132 & 39.821 & 41.953 & 0.57 & 3.02 & 3.59 \\
\hline Hormigueros & 17.250 & 2.845 & 14.405 & 17.250 & 0.85 & 0.00 & 0.85 \\
\hline Humacao & 58.466 & 0.000 & 58.466 & 58.466 & 0.00 & 5.43 & 5.43 \\
\hline Isabela & 45.631 & 0.000 & 45.631 & 45.631 & 0.00 & 6.98 & 6.98 \\
\hline Jayuya & 16.642 & 0.000 & 13.208 & 13.208 & 0.00 & 2.37 & 2.37 \\
\hline Juana Diaz & 50.747 & 22.734 & 27.180 & 49.914 & 5.57 & 0.00 & 5.57 \\
\hline Juncos & 40.290 & 0.000 & 40.290 & 40.290 & 0.13 & 1.56 & 1.69 \\
\hline Lajas & 25.753 & 3.624 & 22.129 & 25.753 & 0.22 & 3.06 & 3.28 \\
\hline
\end{tabular}


Table 1. Estimated population served and public-supply water withdrawals in Puerto Rico by source and municipio, 2010.Continued

[Source: U.S. Geological Survey, Caribbean Water Science Center; withdrawals are accounted in the municipios where the intakes are located; PRASA, Puerto Rico Aqueduct and Sewer Authority; sw, surface water; gw, groundwater; Mgal/d, million gallons per day; some municipios are served exclusively from surface-water systems, exclusively from groundwater wells, and for surface-water systems that are augmented by groundwater]

\begin{tabular}{|c|c|c|c|c|c|c|c|}
\hline \multirow[b]{2}{*}{ Municipio } & \multirow[b]{2}{*}{$\begin{array}{l}2010 \text { Census } \\
\text { of population, } \\
\text { in thousands }\end{array}$} & \multicolumn{6}{|c|}{ PRASA } \\
\hline & & $\begin{array}{l}\text { Population } \\
\text { served by GW, } \\
\text { in thousands }\end{array}$ & $\begin{array}{c}\text { Population } \\
\text { served by SW, } \\
\text { in thousands }\end{array}$ & $\begin{array}{l}\text { Total popula- } \\
\text { tion served, in } \\
\text { thousands }\end{array}$ & $\begin{array}{l}\text { Groundwater } \\
\text { withdrawals, } \\
\text { in Mgal/d }\end{array}$ & $\begin{array}{c}\text { Surface water } \\
\text { withdrawals, } \\
\text { in Mgal/d }\end{array}$ & $\begin{array}{c}\text { Total withdrawals, } \\
\text { in Mgal/d }\end{array}$ \\
\hline Puerto Rico & $3,725.789$ & 296.188 & $3,289.977$ & $3,586.165$ & 83.00 & 587.17 & 670.17 \\
\hline Lares & 30.753 & 0.000 & 29.825 & 29.825 & 0.00 & 3.57 & 3.57 \\
\hline Las Marias & 9.881 & 0.186 & 9.595 & 9.781 & 0.00 & 1.45 & 1.45 \\
\hline Las Piedras & 38.675 & 0.000 & 35.757 & 35.757 & 0.00 & 1.95 & 1.95 \\
\hline Loiza & 30.060 & 0.000 & 29.976 & 29.976 & 0.00 & 0.00 & 0.00 \\
\hline Luquillo & 20.068 & 0.000 & 20.068 & 20.068 & 0.00 & 2.76 & 2.76 \\
\hline Manatí & 44.113 & 3.752 & 40.361 & 44.113 & 4.39 & 0.00 & 4.39 \\
\hline Maricao & 6.276 & 0.000 & 6.176 & 6.176 & 0.00 & 1.62 & 1.62 \\
\hline Maunabo & 12.225 & 0.000 & 11.897 & 11.897 & 1.27 & 0.31 & 1.58 \\
\hline Mayagüez & 89.080 & 1.687 & 83.858 & 85.545 & 1.16 & 23.55 & 24.71 \\
\hline Moca & 40.109 & 4.076 & 29.671 & 33.747 & 1.40 & 0.00 & 1.40 \\
\hline Morovis & 32.610 & 4.350 & 28.260 & 32.610 & 0.32 & 3.30 & 3.62 \\
\hline Naguabo & 26.720 & 0.000 & 22.676 & 22.676 & 0.00 & 17.97 & 17.97 \\
\hline Naranjito & 30.402 & 0.000 & 23.240 & 23.240 & 0.00 & 1.30 & 1.30 \\
\hline Orocovis & 23.423 & 0.000 & 19.121 & 19.121 & 0.00 & 4.23 & 4.23 \\
\hline Patillas & 19.277 & 2.929 & 12.682 & 15.611 & 0.76 & 2.54 & 3.30 \\
\hline Peñuelas & 24.282 & 1.222 & 20.024 & 21.246 & 0.39 & 2.54 & 2.93 \\
\hline Ponce & 166.327 & 7.772 & 155.064 & 162.836 & 3.34 & 1.14 & 4.48 \\
\hline Quebradillas & 25.919 & 5.027 & 20.892 & 25.919 & 0.18 & 3.68 & 3.86 \\
\hline Rincón & 15.200 & 0.000 & 11.404 & 11.404 & 1.63 & 0.00 & 1.63 \\
\hline Rio Grande & 54.304 & 0.000 & 54.044 & 54.044 & 0.00 & 13.96 & 13.96 \\
\hline Sabana Grande & 25.265 & 3.366 & 21.899 & 25.265 & 0.25 & 2.84 & 3.09 \\
\hline Salinas & 31.078 & 25.139 & 4.439 & 29.578 & 3.89 & 0.00 & 3.89 \\
\hline San Germán & 35.527 & 5.509 & 27.132 & 32.641 & 1.46 & 1.13 & 2.59 \\
\hline San Juan & 395.326 & 0.000 & 395.326 & 395.326 & 0.00 & 0.00 & 0.00 \\
\hline San Lorenzo & 41.058 & 0.000 & 37.754 & 37.754 & 0.00 & 5.80 & 5.80 \\
\hline San Sebastián & 42.430 & 2.772 & 38.669 & 41.441 & 0.14 & 4.64 & 4.78 \\
\hline Santa Isabel & 23.274 & 23.274 & 0.000 & 23.274 & 6.92 & 0.00 & 6.92 \\
\hline Toa Alta & 74.066 & 0.000 & 74.066 & 74.066 & 0.00 & 81.51 & 81.51 \\
\hline Toa Baja & 89.609 & 0.000 & 89.609 & 89.609 & 0.00 & 1.97 & 1.97 \\
\hline Trujillo Alto & 74.842 & 0.000 & 74.842 & 74.842 & 0.00 & 103.33 & 103.33 \\
\hline Utuado & 33.149 & 0.000 & 30.717 & 30.717 & 0.00 & 3.96 & 3.96 \\
\hline Vega Alta & 39.951 & 1.863 & 38.088 & 39.951 & 1.56 & 0.00 & 1.56 \\
\hline Vega Baja & 59.662 & 12.085 & 47.577 & 59.662 & 4.39 & 1.71 & 6.10 \\
\hline Vieques & 9.301 & 0.000 & 9.301 & 9.301 & 0.00 & 0.00 & 0.00 \\
\hline Villalba & 26.073 & 2.980 & 20.130 & 23.110 & 0.25 & 32.71 & 32.96 \\
\hline Yabucoa & 37.941 & 10.904 & 16.155 & 27.059 & 1.13 & 2.41 & 3.54 \\
\hline Yauco & 42.043 & 16.873 & 23.155 & 40.028 & 0.79 & 2.49 & 3.28 \\
\hline
\end{tabular}


Table 1. Estimated population served and public-supply water withdrawals in Puerto Rico by source and municipio, 2010.Continued

[Source: U.S. Geological Survey, Caribbean Water Science Center; withdrawals are accounted in the municipios where the intakes are located; PRASA, Puerto Rico Aqueduct and Sewer Authority; sw, surface water; gw, groundwater; Mgal/d, million gallons per day; some municipios are served exclusively from surface-water systems, exclusively from groundwater wells, and for surface-water systems that are augmented by groundwater]

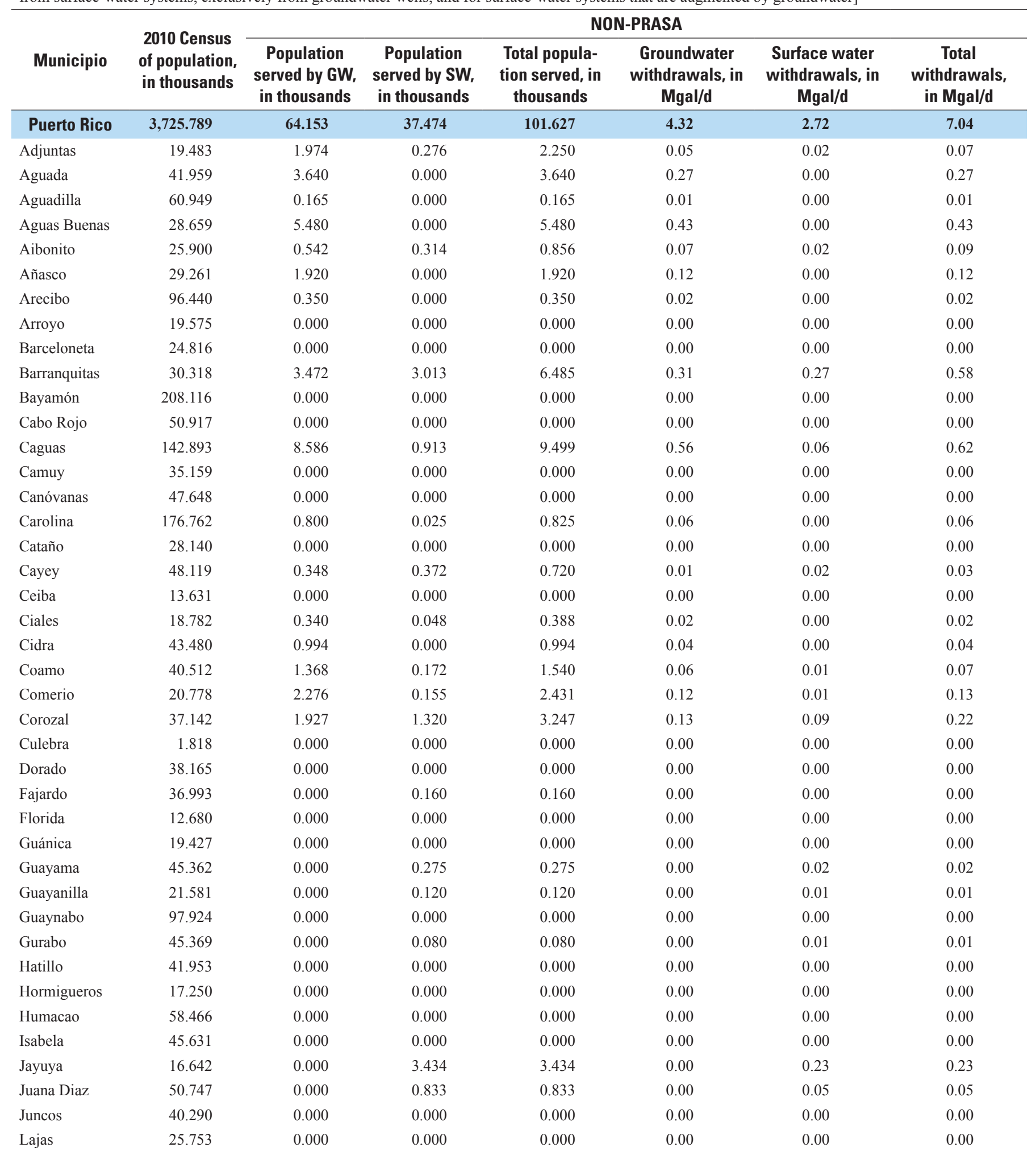


Table 1. Estimated population served and public-supply water withdrawals in Puerto Rico by source and municipio, 2010— Continued

[Source: U.S. Geological Survey, Caribbean Water Science Center; withdrawals are accounted in the municipios where the intakes are located; PRASA, Puerto Rico Aqueduct and Sewer Authority; sw, surface water; gw, groundwater; Mgal/d, million gallons per day; some municipios are served exclusively from surface-water systems, exclusively from groundwater wells, and for surface-water systems that are augmented by groundwater]

\begin{tabular}{|c|c|c|c|c|c|c|c|}
\hline \multirow[b]{2}{*}{ Municipio } & \multirow[b]{2}{*}{$\begin{array}{l}2010 \text { Census } \\
\text { of population, } \\
\text { in thousands }\end{array}$} & \multicolumn{6}{|c|}{ NON-PRASA } \\
\hline & & $\begin{array}{l}\text { Population } \\
\text { served by GW, } \\
\text { in thousands }\end{array}$ & $\begin{array}{l}\text { Population } \\
\text { served by SW, } \\
\text { in thousands }\end{array}$ & $\begin{array}{l}\text { Total popula- } \\
\text { tion served, in } \\
\text { thousands }\end{array}$ & $\begin{array}{c}\text { Groundwater } \\
\text { withdrawals, in } \\
\text { Mgal/d }\end{array}$ & $\begin{array}{c}\text { Surface water } \\
\text { withdrawals, in } \\
\text { Mgal/d }\end{array}$ & $\begin{array}{c}\text { Total } \\
\text { withdrawals, } \\
\text { in Mgal/d }\end{array}$ \\
\hline Puerto Rico & $3,725.789$ & 64.153 & 37.474 & 101.627 & 4.32 & 2.72 & 7.04 \\
\hline Lares & 30.753 & 0.788 & 0.140 & 0.928 & 0.05 & 0.01 & 0.06 \\
\hline Las Marias & 9.881 & 0.000 & 0.100 & 0.100 & 0.00 & 0.01 & 0.01 \\
\hline Loiza & 30.060 & 0.000 & 0.084 & 0.084 & 0.00 & 0.00 & 0.00 \\
\hline Luquillo & 20.068 & 0.000 & 0.000 & 0.000 & 0.00 & 0.00 & 0.00 \\
\hline Manatí & 44.113 & 0.000 & 0.000 & 0.000 & 0.00 & 0.00 & 0.00 \\
\hline Maricao & 6.276 & 0.000 & 0.100 & 0.100 & 0.00 & 0.00 & 0.00 \\
\hline Maunabo & 12.225 & 0.000 & 0.328 & 0.328 & 0.00 & 0.02 & 0.02 \\
\hline Naguabo & 26.720 & 0.000 & 4.044 & 4.044 & 0.00 & 0.40 & 0.40 \\
\hline Naranjito & 30.402 & 7.010 & 0.152 & 7.162 & 0.51 & 0.01 & 0.52 \\
\hline Orocovis & 23.423 & 3.292 & 1.010 & 4.302 & 0.21 & 0.06 & 0.27 \\
\hline Patillas & 19.277 & 0.843 & 2.823 & 3.666 & 0.05 & 0.17 & 0.22 \\
\hline Peñuelas & 24.282 & 0.382 & 2.654 & 3.036 & 0.03 & 0.08 & 0.11 \\
\hline Ponce & 166.327 & 2.336 & 1.155 & 3.491 & 0.13 & 0.07 & 0.20 \\
\hline Quebradillas & 25.919 & 0.000 & 0.000 & 0.000 & 0.00 & 0.00 & 0.00 \\
\hline Rincón & 15.200 & 0.000 & 0.000 & 0.000 & 0.00 & 0.00 & 0.00 \\
\hline Rio Grande & 54.304 & 0.000 & 0.260 & 0.260 & 0.00 & 0.02 & 0.02 \\
\hline Sabana Grande & 25.265 & 0.000 & 0.000 & 0.000 & 0.00 & 0.00 & 0.00 \\
\hline Toa Baja & 89.609 & 0.000 & 0.000 & 0.000 & 0.00 & 0.00 & 0.00 \\
\hline Trujillo Alto & 74.842 & 0.000 & 0.000 & 0.000 & 0.00 & 0.00 & 0.00 \\
\hline Utuado & 33.149 & 0.285 & 2.042 & 2.327 & 0.02 & 0.12 & 0.14 \\
\hline Vega Alta & 39.951 & 0.000 & 0.000 & 0.000 & 0.00 & 0.00 & 0.00 \\
\hline Vega Baja & 59.662 & 0.000 & 0.000 & 0.000 & 0.00 & 0.00 & 0.00 \\
\hline Vieques & 9.301 & 0.000 & 0.000 & 0.000 & 0.00 & 0.00 & 0.00 \\
\hline Villalba & 26.073 & 0.100 & 2.863 & 2.963 & 0.01 & 0.20 & 0.21 \\
\hline Yabucoa & 37.941 & 7.286 & 3.596 & 10.882 & 0.57 & 0.39 & 0.96 \\
\hline Yauco & 42.043 & 0.140 & 1.875 & 2.015 & 0.01 & 0.14 & 0.15 \\
\hline
\end{tabular}


Table 1. Estimated population served and public-supply water withdrawals in Puerto Rico by source and municipio, 2010.Continued

[Source: U.S. Geological Survey, Caribbean Water Science Center; withdrawals are accounted in the municipios where the intakes are located; PRASA, Puerto Rico Aqueduct and Sewer Authority; sw, surface water; gw, groundwater; Mgal/d, million gallons per day; some municipios are served exclusively from surface-water systems, exclusively from groundwater wells, and for surface-water systems that are augmented by groundwater]

\begin{tabular}{|c|c|c|c|c|c|c|c|}
\hline \multirow[b]{2}{*}{ Municipio } & \multirow[b]{2}{*}{$\begin{array}{l}2010 \text { Census } \\
\text { of population, } \\
\text { in thousands }\end{array}$} & \multicolumn{3}{|c|}{ TOTAL POPULATION SERVED } & \multicolumn{3}{|c|}{ TOTAL WITHDRAWALS } \\
\hline & & $\begin{array}{c}\text { Population } \\
\text { served by GW, } \\
\text { in thousands }\end{array}$ & $\begin{array}{c}\text { Population } \\
\text { served by SW, } \\
\text { in thousands }\end{array}$ & $\begin{array}{l}\text { Total Popula- } \\
\text { tion served, in } \\
\text { thousands }\end{array}$ & $\begin{array}{c}\text { Groundwater } \\
\text { withdrawals } \\
\text { in Mgal/d }\end{array}$ & $\begin{array}{c}\text { Surface-water } \\
\text { withdrawals } \\
\text { in Mgal/d }\end{array}$ & $\begin{array}{l}\text { Total withdrawals, } \\
\text { in Mgal/d }\end{array}$ \\
\hline Puerto Rico & $3,725.789$ & 360.341 & $3,327.451$ & $3,687.792$ & 87.32 & 589.89 & 677.21 \\
\hline Adjuntas & 19.483 & 3.196 & 16.287 & 19.483 & 0.12 & 1.03 & 1.15 \\
\hline Aguada & 41.959 & 3.640 & 38.319 & 41.959 & 1.08 & 0.00 & 1.08 \\
\hline Aguadilla & 60.949 & 0.165 & 58.915 & 59.080 & 0.01 & 27.79 & 27.80 \\
\hline Aguas Buenas & 28.659 & 5.480 & 23.179 & 28.659 & 0.71 & 21.07 & 21.78 \\
\hline Aibonito & 25.900 & 0.844 & 21.193 & 22.037 & 0.77 & 3.00 & 3.77 \\
\hline Añasco & 29.261 & 1.920 & 27.341 & 29.261 & 0.55 & 2.19 & 2.74 \\
\hline Arecibo & 96.440 & 8.903 & 83.296 & 92.199 & 14.94 & 103.64 & 118.58 \\
\hline Arroyo & 19.575 & 14.821 & 4.754 & 19.575 & 1.76 & 0.00 & 1.76 \\
\hline Barceloneta & 24.816 & 6.424 & 18.392 & 24.816 & 1.68 & 0.00 & 1.68 \\
\hline Barranquitas & 30.318 & 3.472 & 26.846 & 30.318 & 1.35 & 2.47 & 3.82 \\
\hline Bayamón & 208.116 & 0.000 & 208.116 & 208.116 & 0.00 & 0.19 & 0.19 \\
\hline Cabo Rojo & 50.917 & 0.000 & 50.917 & 50.917 & 4.40 & 1.81 & 6.21 \\
\hline Caguas & 142.893 & 8.586 & 134.307 & 142.893 & 0.61 & 9.07 & 9.68 \\
\hline Camuy & 35.159 & 2.162 & 32.997 & 35.159 & 0.46 & 1.54 & 2.00 \\
\hline Canóvanas & 47.648 & 0.000 & 47.648 & 47.648 & 0.00 & 6.78 & 6.78 \\
\hline Carolina & 176.762 & 0.800 & 175.962 & 176.762 & 0.06 & 0.00 & 0.06 \\
\hline Cataño & 28.140 & 0.000 & 28.140 & 28.140 & 0.00 & 0.00 & 0.00 \\
\hline Cayey & 48.119 & 0.626 & 47.493 & 48.119 & 0.01 & 2.44 & 2.45 \\
\hline Ceiba & 13.631 & 0.000 & 13.631 & 13.631 & 0.00 & 0.00 & 0.00 \\
\hline Ciales & 18.782 & 1.083 & 17.699 & 18.782 & 0.02 & 2.57 & 2.59 \\
\hline Cidra & 43.480 & 0.994 & 37.435 & 38.429 & 0.18 & 5.69 & 5.87 \\
\hline Coamo & 40.512 & 29.926 & 10.586 & 40.512 & 0.15 & 0.85 & 1.00 \\
\hline Comerio & 20.778 & 2.276 & 18.432 & 20.708 & 0.55 & 2.96 & 3.51 \\
\hline Corozal & 37.142 & 1.927 & 32.329 & 34.256 & 0.13 & 3.71 & 3.84 \\
\hline Culebra & 1.818 & 0.000 & 1.818 & 1.818 & 0.00 & 0.00 & 0.00 \\
\hline Dorado & 38.165 & 15.178 & 22.987 & 38.165 & 3.89 & 0.00 & 3.89 \\
\hline Fajardo & 36.993 & 0.000 & 36.993 & 36.993 & 0.00 & 12.12 & 12.12 \\
\hline Florida & 12.680 & 8.454 & 4.226 & 12.680 & 2.20 & 0.00 & 2.20 \\
\hline Guánica & 19.427 & 19.427 & 0.000 & 19.427 & 3.21 & 0.00 & 3.21 \\
\hline Guayama & 45.362 & 4.775 & 40.587 & 45.362 & 0.99 & 12.76 & 13.75 \\
\hline Guayanilla & 21.581 & 18.190 & 3.391 & 21.581 & 2.49 & 0.23 & 2.72 \\
\hline Guaynabo & 97.924 & 0.000 & 95.133 & 95.133 & 0.00 & 8.03 & 8.03 \\
\hline Gurabo & 45.369 & 0.000 & 43.291 & 43.291 & 0.00 & 2.98 & 2.98 \\
\hline Hatillo & 41.953 & 2.132 & 39.821 & 41.953 & 0.57 & 3.02 & 3.59 \\
\hline Hormigueros & 17.250 & 2.845 & 14.405 & 17.250 & 0.85 & 0.00 & 0.85 \\
\hline Humacao & 58.466 & 0.000 & 58.466 & 58.466 & 0.00 & 5.43 & 5.43 \\
\hline Isabela & 45.631 & 0.000 & 45.631 & 45.631 & 0.00 & 6.98 & 6.98 \\
\hline Jayuya & 16.642 & 0.000 & 16.642 & 16.642 & 0.00 & 2.60 & 2.60 \\
\hline Juana Diaz & 50.747 & 22.734 & 28.013 & 50.747 & 5.57 & 0.05 & 5.62 \\
\hline Juncos & 40.290 & 0.000 & 40.290 & 40.290 & 0.13 & 1.56 & 1.69 \\
\hline Lajas & 25.753 & 3.624 & 22.129 & 25.753 & 0.22 & 3.06 & 3.28 \\
\hline
\end{tabular}


Table 1. Estimated population served and public-supply water withdrawals in Puerto Rico by source and municipio, 2010.Continued

[Source: U.S. Geological Survey, Caribbean Water Science Center; withdrawals are accounted in the municipios where the intakes are located; PRASA, Puerto Rico Aqueduct and Sewer Authority; sw, surface water; gw, groundwater; Mgal/d, million gallons per day; some municipios are served exclusively from surface-water systems, exclusively from groundwater wells, and for surface-water systems that are augmented by groundwater]

\begin{tabular}{|c|c|c|c|c|c|c|c|}
\hline \multirow[b]{2}{*}{ Municipio } & \multirow[b]{2}{*}{$\begin{array}{l}2010 \text { Census } \\
\text { of population, } \\
\text { in thousands }\end{array}$} & \multicolumn{3}{|c|}{ TOTAL POPULATION SERVED } & \multicolumn{3}{|c|}{ TOTAL WITHDRAWALS } \\
\hline & & $\begin{array}{c}\text { Population } \\
\text { served by GW, } \\
\text { in thousands }\end{array}$ & $\begin{array}{c}\text { Population } \\
\text { served by SW, } \\
\text { in thousands }\end{array}$ & $\begin{array}{l}\text { Total Popula- } \\
\text { tion served, in } \\
\text { thousands }\end{array}$ & $\begin{array}{c}\text { Groundwater } \\
\text { withdrawals } \\
\text { in Mgal/d }\end{array}$ & $\begin{array}{c}\text { Surface-water } \\
\text { withdrawals in } \\
\text { Mgal/d }\end{array}$ & $\begin{array}{c}\text { Total } \\
\text { withdrawals, } \\
\text { in Mgal/d }\end{array}$ \\
\hline Puerto Rico & $3,725.789$ & 360.341 & $3,327.451$ & $3,687.792$ & 87.32 & 589.89 & 677.21 \\
\hline Lares & 30.753 & 0.788 & 29.965 & 30.753 & 0.05 & 3.58 & 3.63 \\
\hline Las Marias & 9.881 & 0.186 & 9.695 & 9.881 & 0.00 & 1.46 & 1.46 \\
\hline Las Piedras & 38.675 & 2.008 & 36.667 & 38.675 & 0.12 & 2.00 & 2.12 \\
\hline Loiza & 30.060 & 0.000 & 30.060 & 30.060 & 0.00 & 0.00 & 0.00 \\
\hline Luquillo & 20.068 & 0.000 & 20.068 & 20.068 & 0.00 & 2.76 & 2.76 \\
\hline Manatí & 44.113 & 3.752 & 40.361 & 44.113 & 4.39 & 0.00 & 4.39 \\
\hline Maricao & 6.276 & 0.000 & 6.276 & 6.276 & 0.00 & 1.62 & 1.62 \\
\hline Maunabo & 12.225 & 0.000 & 12.225 & 12.225 & 1.27 & 0.33 & 1.60 \\
\hline Mayagüez & 89.080 & 1.687 & 83.858 & 85.545 & 1.16 & 23.55 & 24.71 \\
\hline Moca & 40.109 & 4.076 & 29.671 & 33.747 & 1.40 & 0.00 & 1.40 \\
\hline Morovis & 32.610 & 4.350 & 28.260 & 32.610 & 0.32 & 3.30 & 3.62 \\
\hline Naguabo & 26.720 & 0.000 & 26.720 & 26.720 & 0.00 & 18.37 & 18.37 \\
\hline Naranjito & 30.402 & 7.010 & 23.392 & 30.402 & 0.51 & 1.31 & 1.82 \\
\hline Orocovis & 23.423 & 3.292 & 20.131 & 23.423 & 0.21 & 4.29 & 4.50 \\
\hline Patillas & 19.277 & 3.772 & 15.505 & 19.277 & 0.81 & 2.71 & 3.52 \\
\hline Peñuelas & 24.282 & 1.604 & 22.678 & 24.282 & 0.42 & 2.62 & 3.04 \\
\hline Ponce & 166.327 & 10.108 & 156.219 & 166.327 & 3.47 & 1.21 & 4.68 \\
\hline Quebradillas & 25.919 & 5.027 & 20.892 & 25.919 & 0.18 & 3.68 & 3.86 \\
\hline Rincón & 15.200 & 0.000 & 11.404 & 11.404 & 1.63 & 0.00 & 1.63 \\
\hline Rio Grande & 54.304 & 0.000 & 54.304 & 54.304 & 0.00 & 13.98 & 13.98 \\
\hline Sabana Grande & 25.265 & 3.366 & 21.899 & 25.265 & 0.25 & 2.84 & 3.09 \\
\hline Salinas & 31.078 & 26.639 & 4.439 & 31.078 & 3.99 & 0.00 & 3.99 \\
\hline San Germán & 35.527 & 5.665 & 28.512 & 34.177 & 1.47 & 1.25 & 2.72 \\
\hline San Juan & 395.326 & 0.000 & 395.326 & 395.326 & 0.00 & 0.00 & 0.00 \\
\hline San Lorenzo & 41.058 & 2.856 & 38.202 & 41.058 & 0.18 & 5.83 & 6.01 \\
\hline San Sebastián & 42.430 & 3.761 & 38.669 & 42.430 & 0.18 & 4.64 & 4.82 \\
\hline Santa Isabel & 23.274 & 23.274 & 0.000 & 23.274 & 6.92 & 0.00 & 6.92 \\
\hline Toa Alta & 74.066 & 0.000 & 74.066 & 74.066 & 0.00 & 81.51 & 81.51 \\
\hline Toa Baja & 89.609 & 0.000 & 89.609 & 89.609 & 0.00 & 1.97 & 1.97 \\
\hline Trujillo Alto & 74.842 & 0.000 & 74.842 & 74.842 & 0.00 & 103.33 & 103.33 \\
\hline Utuado & 33.149 & 0.285 & 32.759 & 33.044 & 0.02 & 4.08 & 4.10 \\
\hline Vega Alta & 39.951 & 1.863 & 38.088 & 39.951 & 1.56 & 0.00 & 1.56 \\
\hline Vega Baja & 59.662 & 12.085 & 47.577 & 59.662 & 4.39 & 1.71 & 6.10 \\
\hline Vieques & 9.301 & 0.000 & 9.301 & 9.301 & 0.00 & 0.00 & 0.00 \\
\hline Villalba & 26.073 & 3.080 & 22.993 & 26.073 & 0.26 & 32.91 & 33.17 \\
\hline Yabucoa & 37.941 & 18.190 & 19.751 & 37.941 & 1.70 & 2.80 & 4.50 \\
\hline Yauco & 42.043 & 17.013 & 25.030 & 42.043 & 0.80 & 2.63 & 3.43 \\
\hline
\end{tabular}




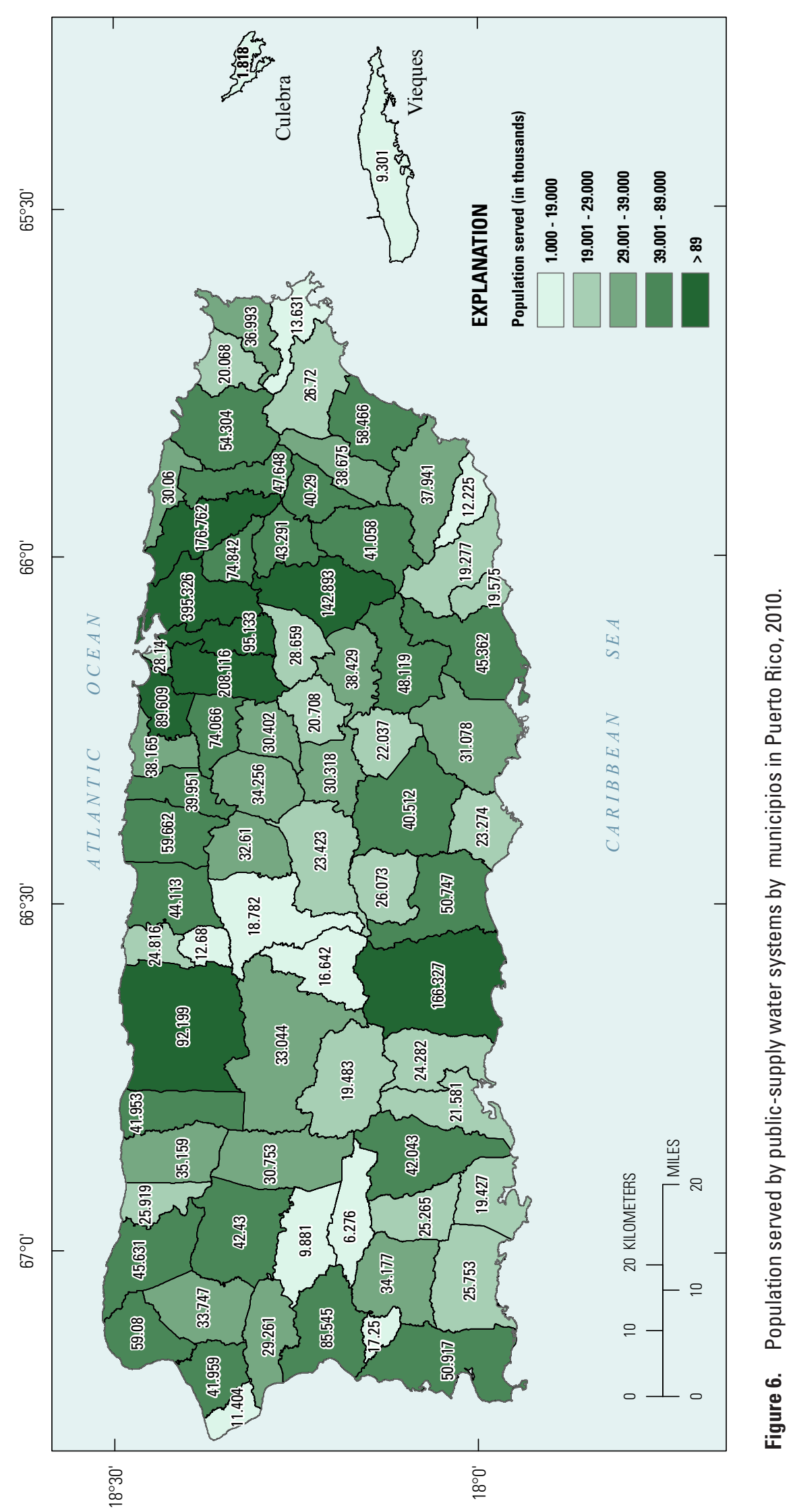




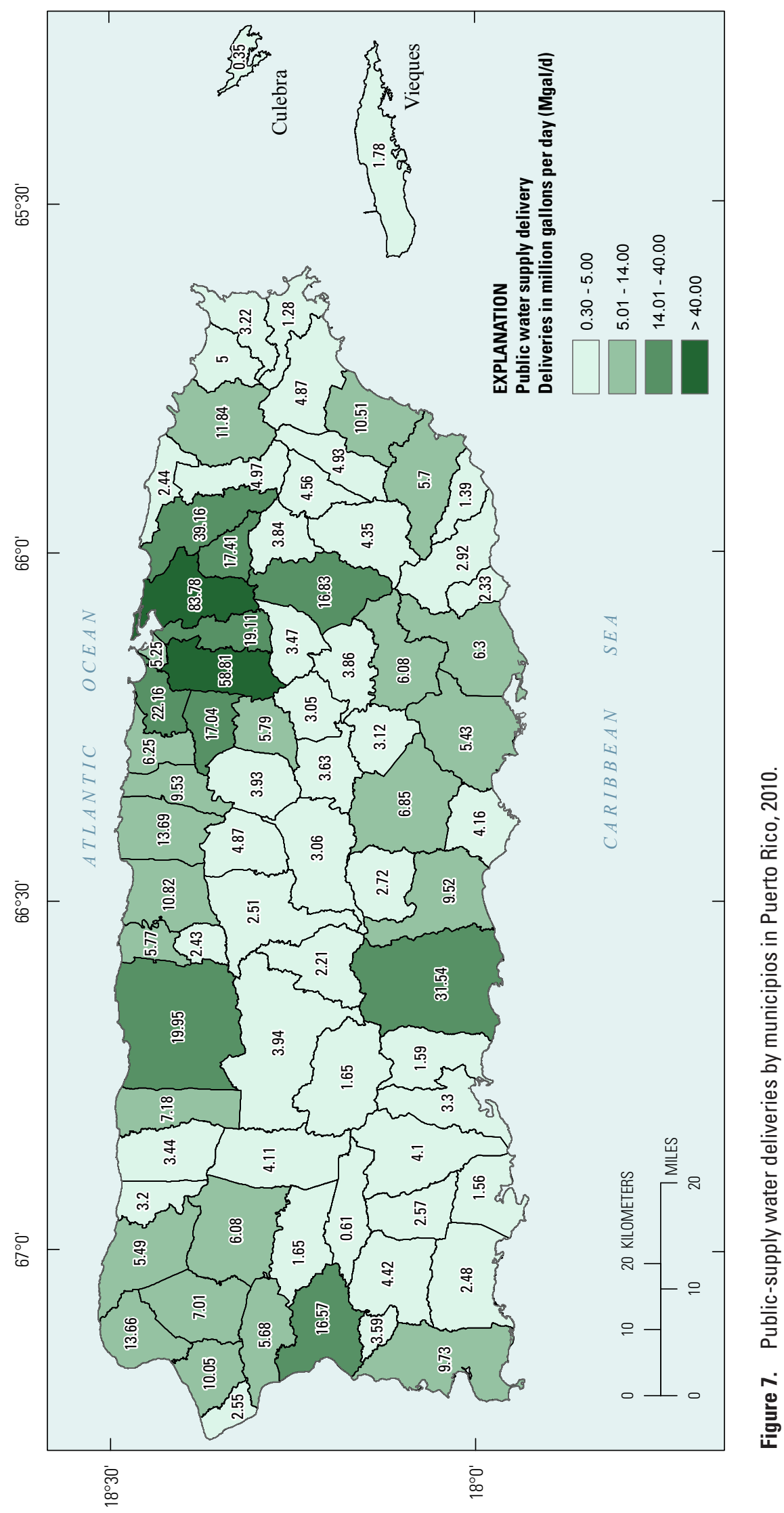




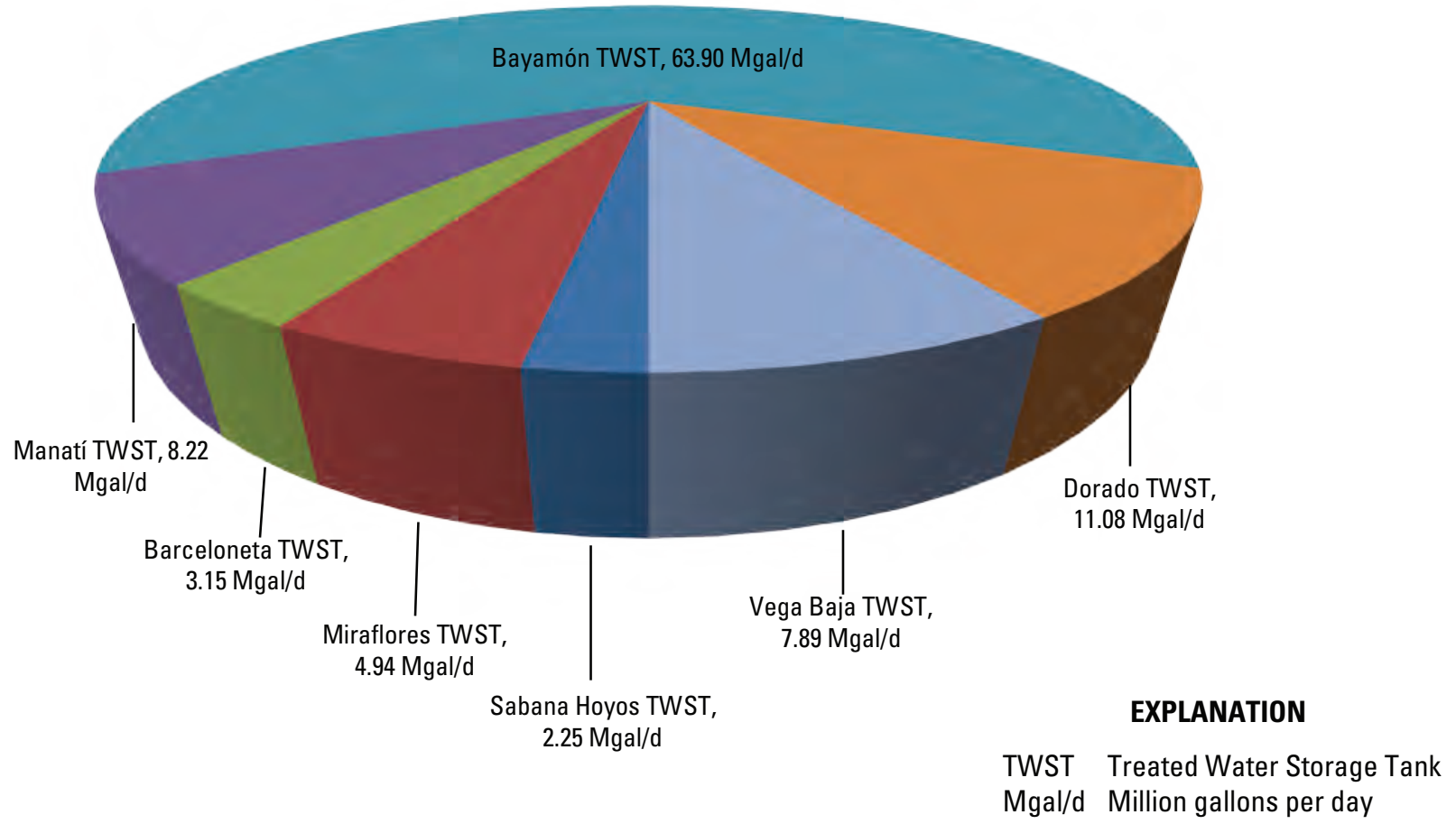

Figure 8. Water deliveries among the North Coast Aqueduct interconnections in Puerto Rico. 

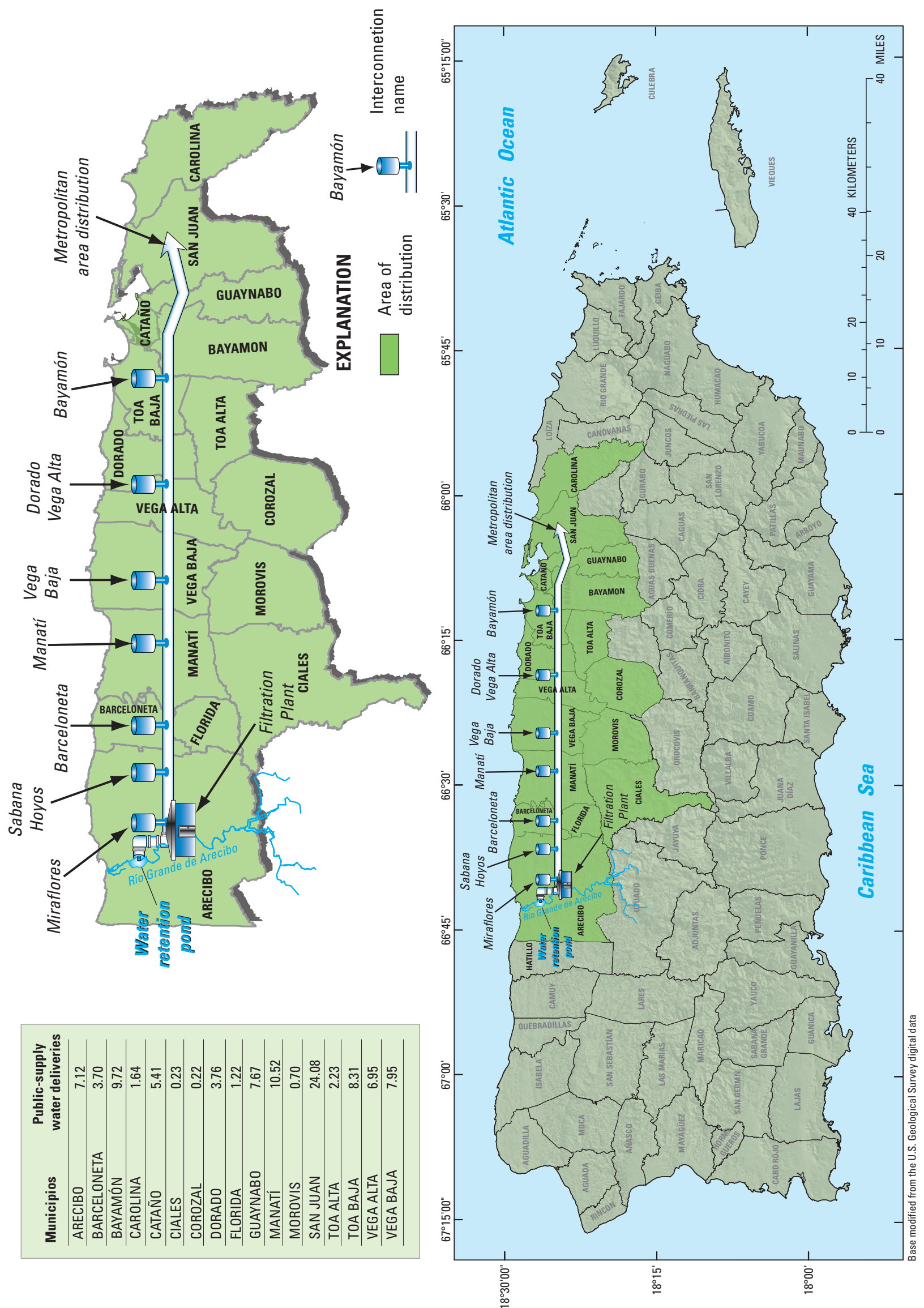

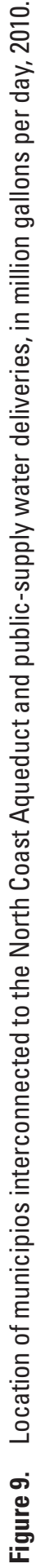

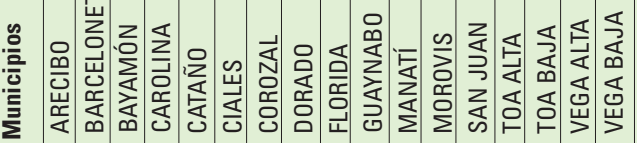

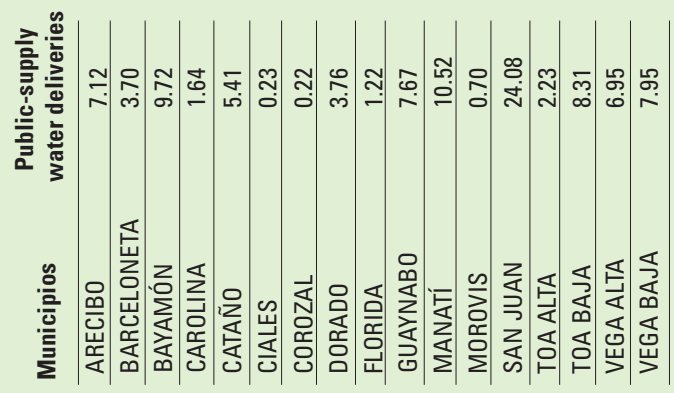




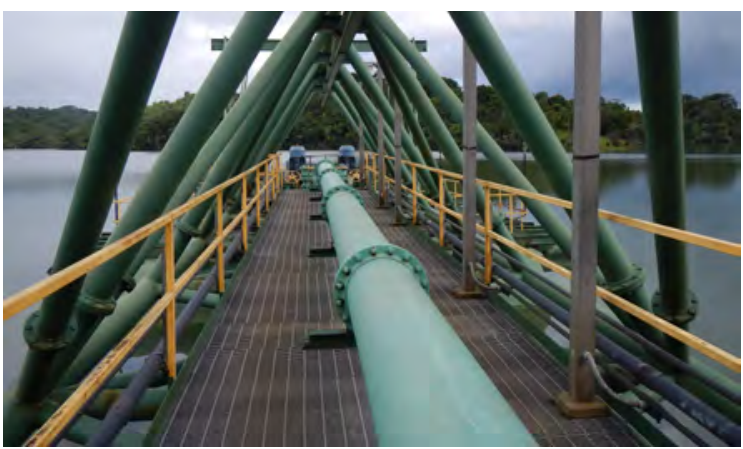

Example of surface-water intake located in southeastern Puerto Rico, photograph by Jessie Juarbe, September 13, 2013.

Public-supply water deliveries include $206 \mathrm{Mgal} / \mathrm{d}$ of water for domestic use, and $457 \mathrm{Mgal} / \mathrm{d}$ of water for commercial, industrial, thermoelectric power, and public facilities (the use of water by government facilities such as schools, hospitals, public offices, and for fire hydrants). Public-supply water by the non-PRASA systems is used for domestic purposes by community-operated water systems that supply water to the same population year-round (water systems that usually serve rural areas). Non-PRASA systems are considered public-water suppliers, because they provide piped water for human consumption and have at least 15 service connections or regularly serve an average of at least 25 people at least 60 days per year (U.S. Environmental Protection Agency, 2012).

\section{Public-Supply Water Domestic Use}

In 2010, domestic use delivered by public-supply water system in Puerto Rico was estimated at $206 \mathrm{Mgal} / \mathrm{d}$, (PRASA and non-PRASA systems). The PRASA system delivered $198 \mathrm{Mgal} / \mathrm{d}$ or about 30 percent of the total PRASA deliveries from surface-water and groundwater sources. The remaining was delivered from non-PRASA systems. The domestic per capita use for Puerto Rico was estimated at 56 gallons per day (gal/d) per person in 2010 (table 2). Domestic per capita use varies from municipio to municipio (fig. 10); however, households served by the same public-supply water system often have a common pattern of use affected by factors such as customer affluence, climate, and topography among other factors. About 50 percent of the 78 municipios in Puerto Rico had a domestic per capita use coefficient fluctuating between 53 and $60 \mathrm{gal} / \mathrm{d}$ per person during 2010 (fig. 10).

Economic constraint indicators such as water rate cost increases, reduction in the Puerto Rico's resident population, the implementation of low-flow fixtures and domestic conservation programs are some factors affecting the reduction of domestic per capita use in Puerto Rico during 2010. The U.S. Census Bureau indicated that Puerto Rico's resident population decreased 2 percent from the population counted a decade earlier (U.S. Census Bureau, 2010), which may affect the domestic per capita use reduction by about 40 percent; from $91 \mathrm{gal} / \mathrm{d}$ per person in 2005 to $56 \mathrm{gal} / \mathrm{d}$ per person in 2010 .

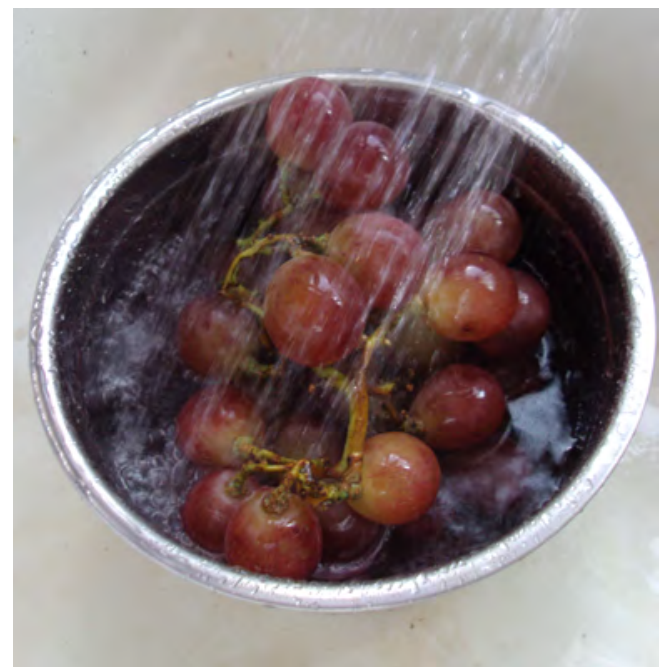

Example of household water use, photograph by Wanda L. Molina, January, 2009.

\section{Domestic Self-Supplied Water Use}

In 2010, domestic self-supplied water use was estimated at $2.41 \mathrm{Mgal} / \mathrm{d}$. About 38 thousand residents or about 1 percent of the population in Puerto Rico relies on private wells or springs for their household water needs. Self-supplied domestic water use was derived by multiplying the domestic self-supplied population by the domestic per capita use coefficient determined for the municipio, which are presented in table 3 as domestic per capita use in gallons per day per person.

The importance of groundwater resources in Puerto Rico, for public-supply water needs and as the source for self-supplied domestic users, is indicated by the distribution of withdrawals given in table 3 .

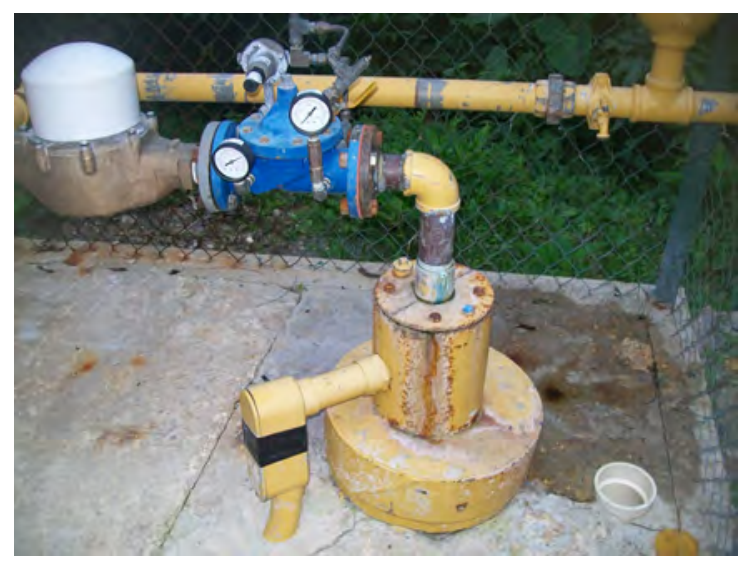

Example of plumbing configuration used by domestic wells in Puerto Rico, photograph by Jessie Juarbe, July 18, 2011.

\section{Industrial Self-Supplied Withdrawals}

In 2010, industrial self-supplied groundwater withdrawal was estimated at $4.30 \mathrm{Mgal} / \mathrm{d}$. Water for industrial uses at facilities requiring relatively large amounts of water as part of industrial processes is obtained from self-supplied groundwater withdrawals. Industrial facilities requiring lesser 
amounts of water that are typically supplied from public-supply water facilities were not included in this report. In 2010, the municipios with the largest industrial groundwater withdrawals were Arecibo, Manatí and Barceloneta. The NAICS 325412 (U.S. Census Bureau, 2012), which corresponds to pharmaceutical products manufacturing, accounted for 65 percent of the total industrial self-supplied groundwater withdrawals on Puerto Rico. Yabucoa had substantial industrial activity related to the refining of petroleum products, which uses about 9 percent of the total industrial self-supplied withdrawals. Industrial self-supplied withdrawals from groundwater sources in Puerto Rico by municipio in 2010 are presented in table 4 .

\section{Crop-Irrigation Water Use}

During 2010, the estimated irrigation withdrawals and water deliveries to farms in Puerto Rico averaged $38.2 \mathrm{Mgal} / \mathrm{d}$ from an estimate of 40.2 thousand cultivated acres (table 5). Minor crops such as vegetables and fruits accounted for 18.3 thousand cultivated acres, followed by 14.2 thousand acres cultivated for coffee and plantains. Cultivated acres for pineapples accounted for 7.72 thousand in Lajas Valley. About 33 thousand acres were irrigated using low-volume micro-irrigation systems; whereas the remaining 7.72 thousand acres used sprinkler irrigation systems, primarily for pineapple crops in Lajas Valley (table 5).

Crop-irrigation water use during calendar year 2010 was primarily withdrawn from groundwater sources. Groundwater aquifers provided $22.4 \mathrm{Mgal} / \mathrm{d}$ out of $38.2 \mathrm{Mgal} / \mathrm{d}$ for irrigation water use in Puerto Rico. Most of the groundwater withdrawals $(19.4 \mathrm{Mgal} / \mathrm{d})$ were from aquifers located in the south coast, from Arroyo to Lajas Valley. The remaining 3.01 Mgal/d were withdrawn from aquifers located in the north, east and west coasts of Puerto Rico.

The four major irrigation systems operated by the PREPA: the Guayama and Juana Díaz Irrigation Districts on the south coast; the Valle de Lajas Irrigation District in the southwest, and the Isabela Irrigation District in northwestern Puerto Rico delivered $15.7 \mathrm{Mgal} / \mathrm{d}$ of surface water for irrigation in 2010 (table 5).

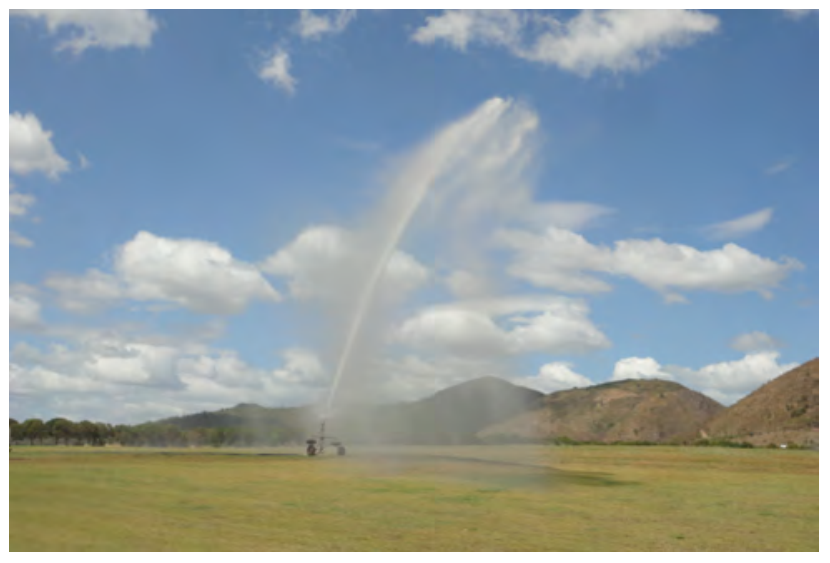

Farm irrigated by a sprinkler system in the south coast of Puerto Rico, photograph by Marcos Quiñones, February 24, 2014.

\section{Thermoelectric-Power Water Use}

In 2010, Puerto Rico had four thermoelectric powerplants operated by PREPA and located in Cataño, Guayanilla, Salinas and San Juan (fig. 4). In addition, there were two non-PREPA thermoelectric facilities located in Guayama and Peñuelas. Water use data for non-PREPA thermoelectric facilities were not included in this report.

Seawater used for cooling was estimated at 2,262 Mgal/d; the PRASA delivered an estimated total of $1.77 \mathrm{Mgal} / \mathrm{d}$ of freshwater to the Cataño and San Juan powerplants. Total groundwater withdrawals by the powerplants located in Guayanilla and Salinas were $1.15 \mathrm{Mgal} / \mathrm{d}$. The PREPA plant located in Guayanilla received $0.52 \mathrm{Mgal} / \mathrm{d}$ of freshwater produced by a desalination plant in a non-PREPA thermoelectric facility located in the area. The four PREPA thermoelectric plants generated 13,545 gigawatt-hour ( $\mathrm{gWh}$ ) of electricity during 2010 (table 6).

\section{Hydroelectric-Power Instream Water Use}

In 2010, Puerto Rico had nine active hydroelectric powerplants located in Arecibo (Dos Bocas), Naguabo (Rio Blanco) Orocovis (Toro Negro 2), Peñuelas (Rio Garzas 1 and 2), Utuado (Caonillas 1), Villalba (Toro Negro 1), and Yauco (Yauco 1 and 2) (fig. 5). These powerplants generated $159 \mathrm{gWh}$ of electricity in 2010 with a total-instream freshwater use of about $556 \mathrm{Mgal} / \mathrm{d}$ (622,179 acre-feet per year). In 2010, about 32 percent of all hydroelectric power in Puerto Rico was generated by the Dos Bocas powerplant (51gWh) (table 7).

\section{Total Water Use}

Total water use in Puerto Rico in 2010 was estimated for: public-supply water withdrawals and deliveries, domestic self-supplied water use, industrial self-supplied withdrawal, crop-irrigation water use, thermoelectric-power freshwater use, and hydroelectric power. Public-supply water delivered for domestic use and population served also were estimated. Total offstream freshwater withdrawals in 2010 were estimated at about $724 \mathrm{Mgal} / \mathrm{d}$ and instream water withdrawals were estimated at 2,818 Mgal/d. Instream water withdrawals included the saline water withdrawals used for cooling at thermoelectric plants $(2,262 \mathrm{Mgal} / \mathrm{d})$ and freshwater withdrawals from the island's streams used for hydroelectric power (556 Mgal/d) (table 8 ).

Total freshwater withdrawals by offstream water-use categories accounted for $724 \mathrm{Mgal} / \mathrm{d}$ and are listed in table 9. Public-supply water use accounted for the largest freshwater withdrawal (677 Mgal/d), followed by crop irrigation with $38.2 \mathrm{Mgal} / \mathrm{d}$. 
Table 2. Estimated deliveries from public- supply water systems to domestic use, population served and domestic per capita use in Puerto Rico by source and municipio, 2010.

[Source: U.S. Geological Survey, Caribbean Water Science Center; PRASA, Puerto Rico Aqueduct and Sewer Authority; sw, surface water; gw, groundwater; $\mathrm{Mgal} / \mathrm{d}$, million gallons per day; gal/d-p, gallons per day per person]

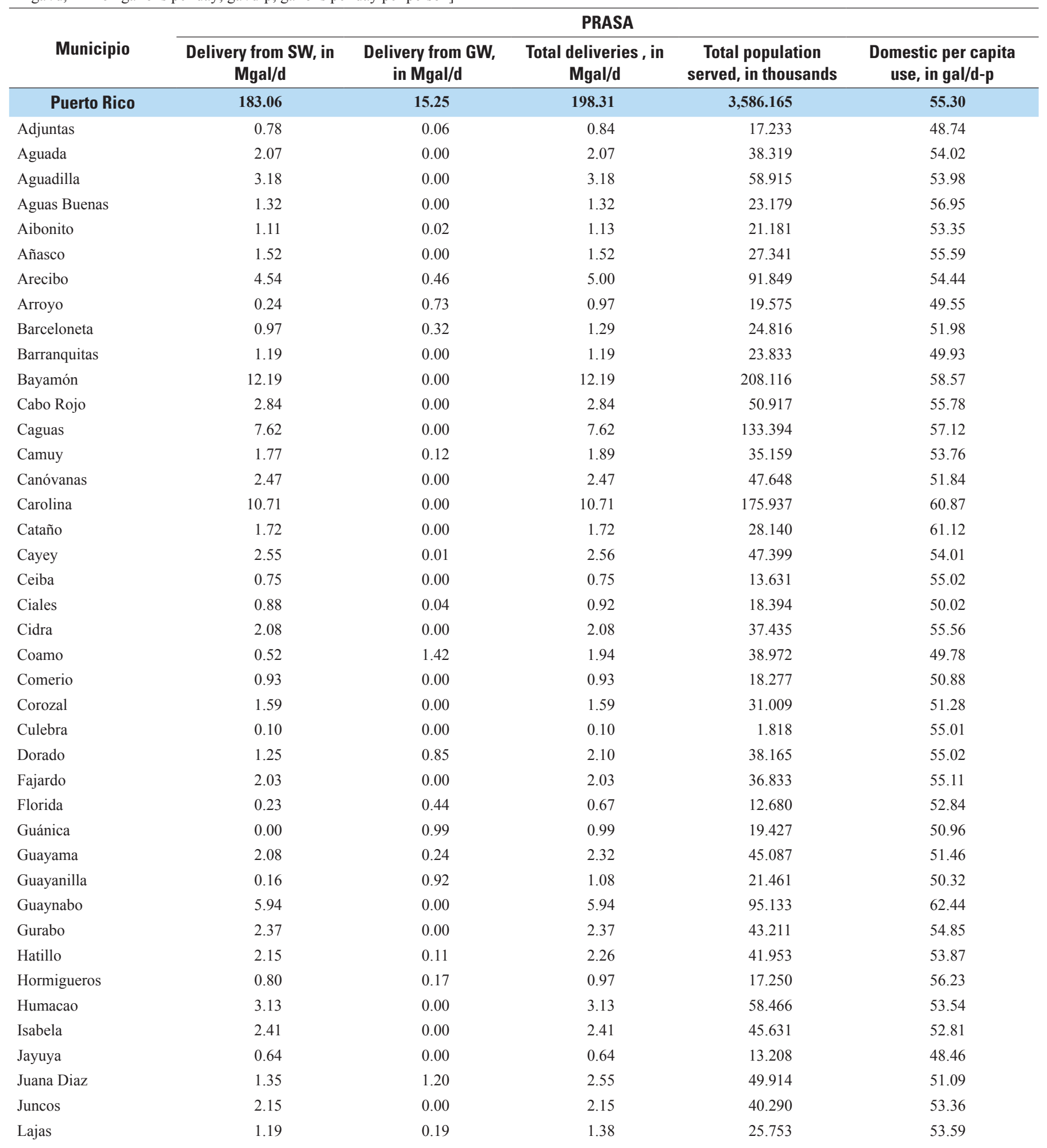


Table 2. Estimated deliveries from public- supply water systems to domestic use, population served and domestic per capita use in Puerto Rico by source and municipio, 2010.-Continued

[Source: U.S. Geological Survey, Caribbean Water Science Center; PRASA, Puerto Rico Aqueduct and Sewer Authority; sw, surface water; gw, groundwater; $\mathrm{Mgal} / \mathrm{d}$, million gallons per day; gal/d-p, gallons per day per person]

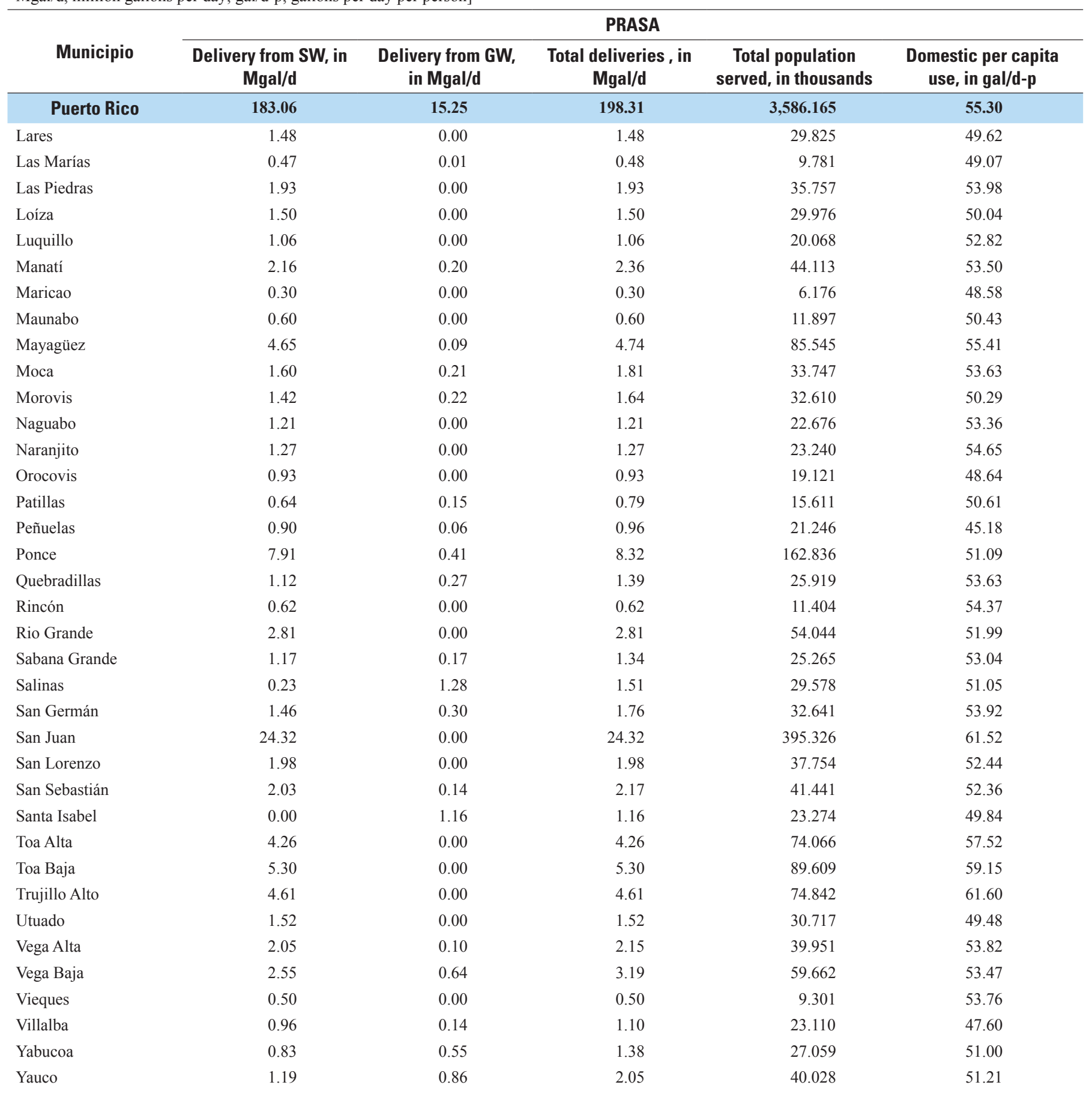


Table 2. Estimated deliveries from public- supply water systems to domestic use, population served and domestic per capita use in Puerto Rico by source and municipio, 2010.-Continued

[Source: U.S. Geological Survey, Caribbean Water Science Center; PRASA, Puerto Rico Aqueduct and Sewer Authority; sw, surface water; gw, groundwater; $\mathrm{Mgal} / \mathrm{d}$, million gallons per day; gal/d-p, gallons per day per person]

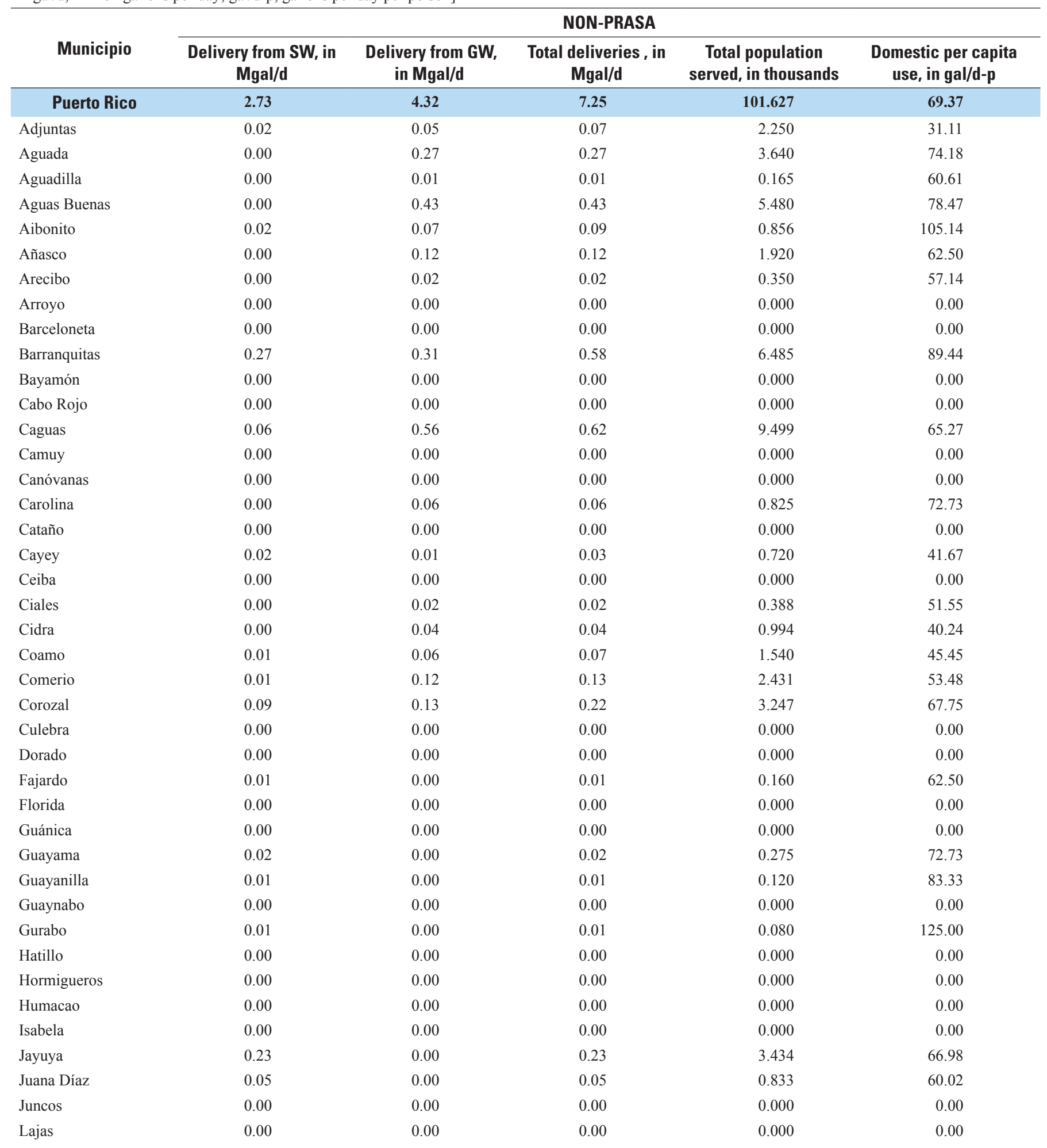


Table 2. Estimated deliveries from public- supply water systems to domestic use, population served and domestic per capita use in Puerto Rico by source and municipio, 2010.-Continued

[Source: U.S. Geological Survey, Caribbean Water Science Center; PRASA, Puerto Rico Aqueduct and Sewer Authority; sw, surface water; gw, groundwater; $\mathrm{Mgal} / \mathrm{d}$, million gallons per day; gal/d-p, gallons per day per person]

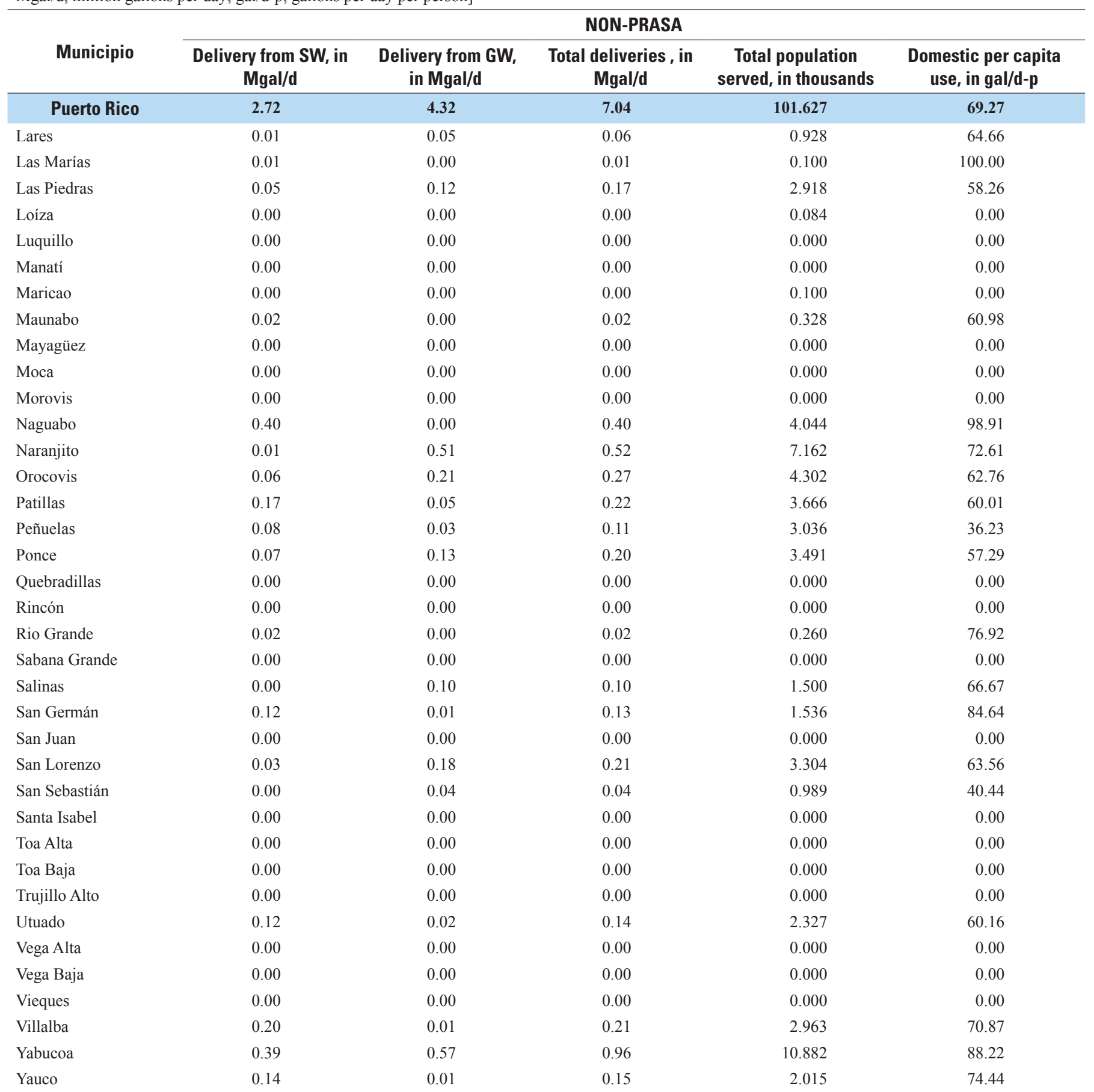


Table 2. Estimated deliveries from public-supply water systems to domestic use, population served and domestic per capita use in Puerto Rico by source and municipio, 2010.-Continued

[Source: U.S. Geological Survey, Caribbean Water Science Center; PRASA, Puerto Rico Aqueduct and Sewer Authority; sw, surface water; gw, groundwater; $\mathrm{Mgal} / \mathrm{d}$, million gallons per day; gal/d-p, gallons per day per person]

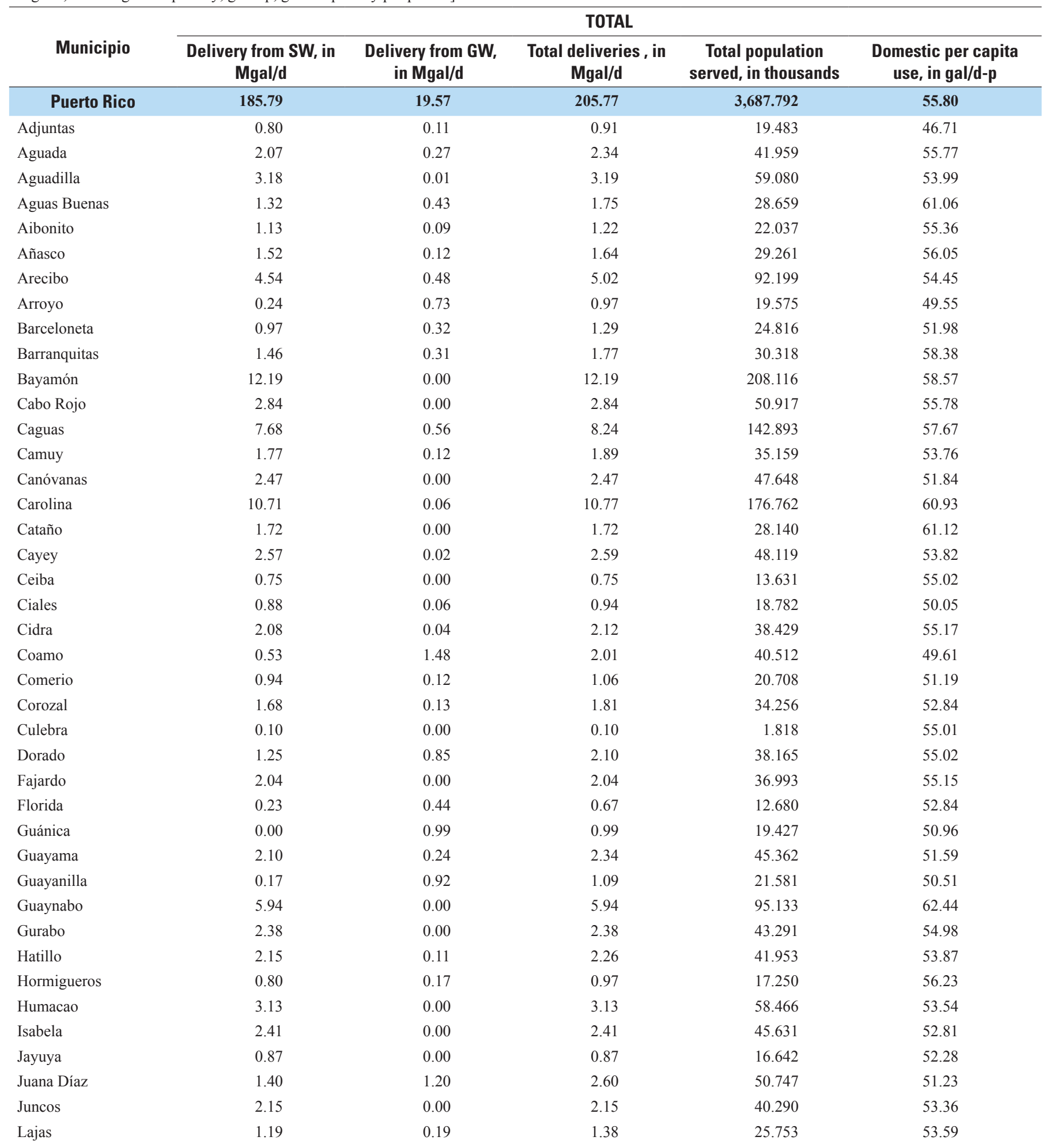


Table 2. Estimated deliveries from public- supply water systems to domestic use, population served and domestic per capita use in Puerto Rico by source and municipio, 2010.-Continued

[Source: U.S. Geological Survey, Caribbean Water Science Center; PRASA, Puerto Rico Aqueduct and Sewer Authority; sw, surface water; gw, groundwater; $\mathrm{Mgal} / \mathrm{d}$, million gallons per day; gal/d-p, gallons per day per person]

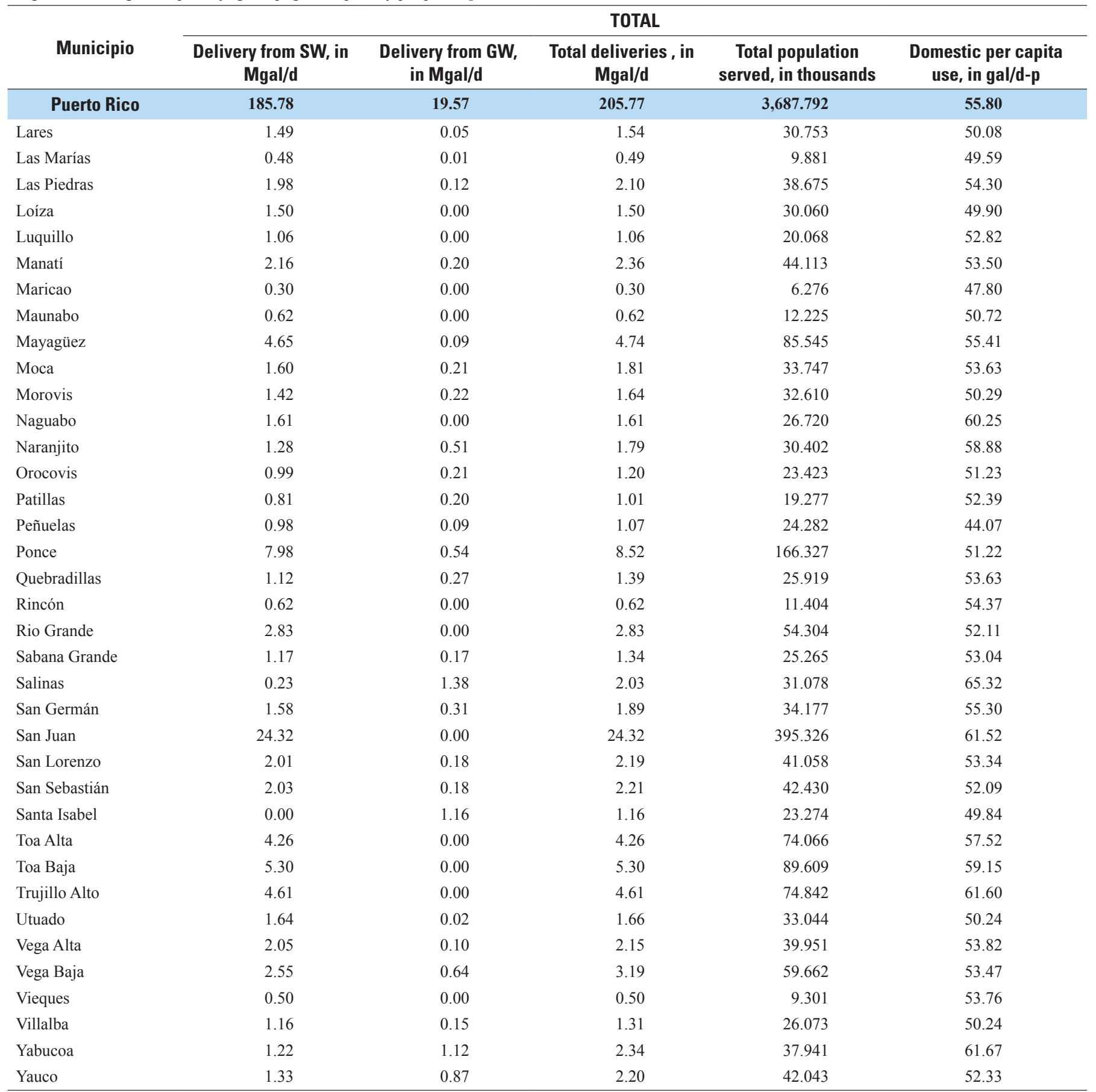




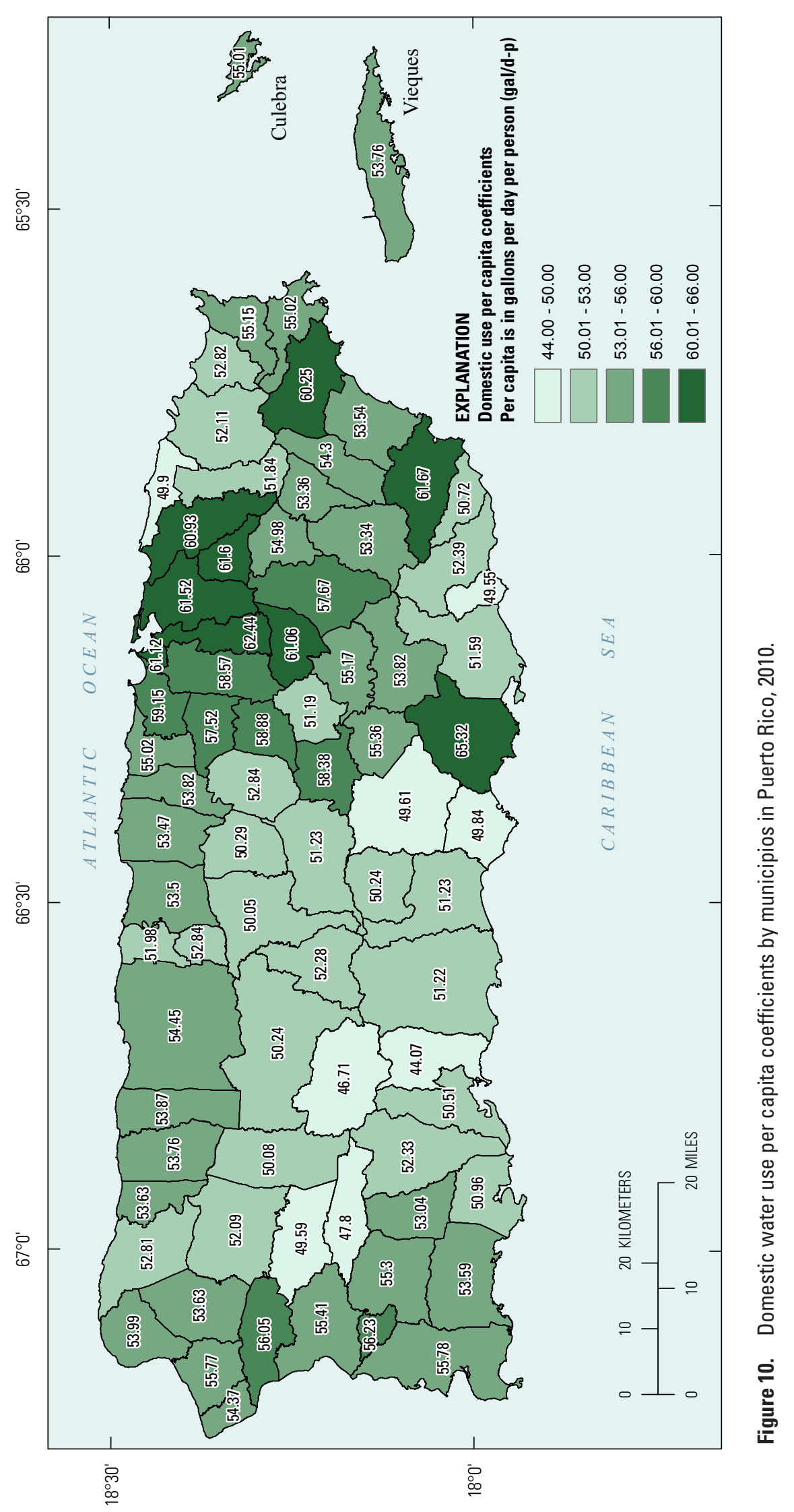


Table 3. Estimated domestic self-supplied withdrawals from groundwater sources, population served and domestic per capita use in Puerto Rico by municipio, 2010.

[Source: U.S. Geological Survey, Caribbean Water Science Center; Mgal/d, million gallons per day; gal/d-p, gallons per day per person]

\begin{tabular}{lcrc}
\hline Municipio & $\begin{array}{r}\text { Withdrawals, } \\
\text { in Mgal/d }\end{array}$ & $\begin{array}{r}\text { Population } \\
\text { served, in } \\
\text { thousands }\end{array}$ & $\begin{array}{r}\text { Domestic per capita } \\
\text { use , in gal/d-p }\end{array}$ \\
\hline Puerto Rico & $\mathbf{2 . 4 1}$ & $\mathbf{3 7 . 9 2 7}$ & $\mathbf{6 3 . 5 4}$ \\
Aguadilla & 0.12 & 1.869 & 64.21 \\
Aibonito & 0.27 & 3.863 & 69.89 \\
Arecibo & 0.28 & 4.241 & 66.02 \\
Cidra & 0.23 & 5.051 & 45.54 \\
Corozal & 0.20 & 2.886 & 69.30 \\
Guaynabo & 0.19 & 2.791 & 68.08 \\
Gurabo & 0.14 & 2.078 & 67.37 \\
Mayagüez & 0.20 & 3.535 & 56.58 \\
Moca & 0.40 & 6.362 & 62.87 \\
Rincón & 0.25 & 3.796 & 65.86 \\
San Germán & 0.12 & 1.350 & 88.89 \\
Utuado & 0.01 & 0.105 & 95.24 \\
\hline
\end{tabular}

Table 4. Industrial self-supplied withdrawals from groundwater sources in Puerto Rico by municipio, 2010.

[Source: U.S. Geological Survey, Caribbean Water Science Center; all values in million gallons per day]

\begin{tabular}{lc}
\hline \multicolumn{1}{c}{ Municipio } & Withdrawals \\
\hline Puerto Rico & $\mathbf{4 . 3 0}$ \\
Aguada & 0.00 \\
Aguadilla & 0.02 \\
Aibonito & 0.23 \\
Añasco & 0.00 \\
Arecibo & 0.84 \\
Barceloneta & 0.46 \\
Bayamón & 0.20 \\
Caguas & 0.03 \\
Carolina & 0.04 \\
Cayey & 0.35 \\
Cidra & 0.08 \\
Fajardo & 0.08 \\
Guayama & 0.40 \\
Humacao & 0.04 \\
Jayuya & 0.03 \\
Juncos & 0.00 \\
Las Piedras & 0.10 \\
Manatí & 0.49 \\
Maricao & 0.05 \\
Peñuelas & 0.04 \\
Salinas & 0.01 \\
San Juan & 0.07 \\
San Lorenzo & 0.01 \\
Toa Baja & 0.28 \\
Vega Baja & 0.08 \\
Yabucoa & 0.37 \\
\hline
\end{tabular}


Table 5. Estimated irrigation water use, cultivated and irrigated acres and irrigation methods in Puerto Rico by source and municipio, 2010.

[Source: U.S. Geological Survey, Caribbean Water Science Center; Mgal/d, million gallons per day; cultivated and irrigated acres in thousands; sw, surface water; gw, groundwater; mi, micro-irrigation; N/A, not applicable]

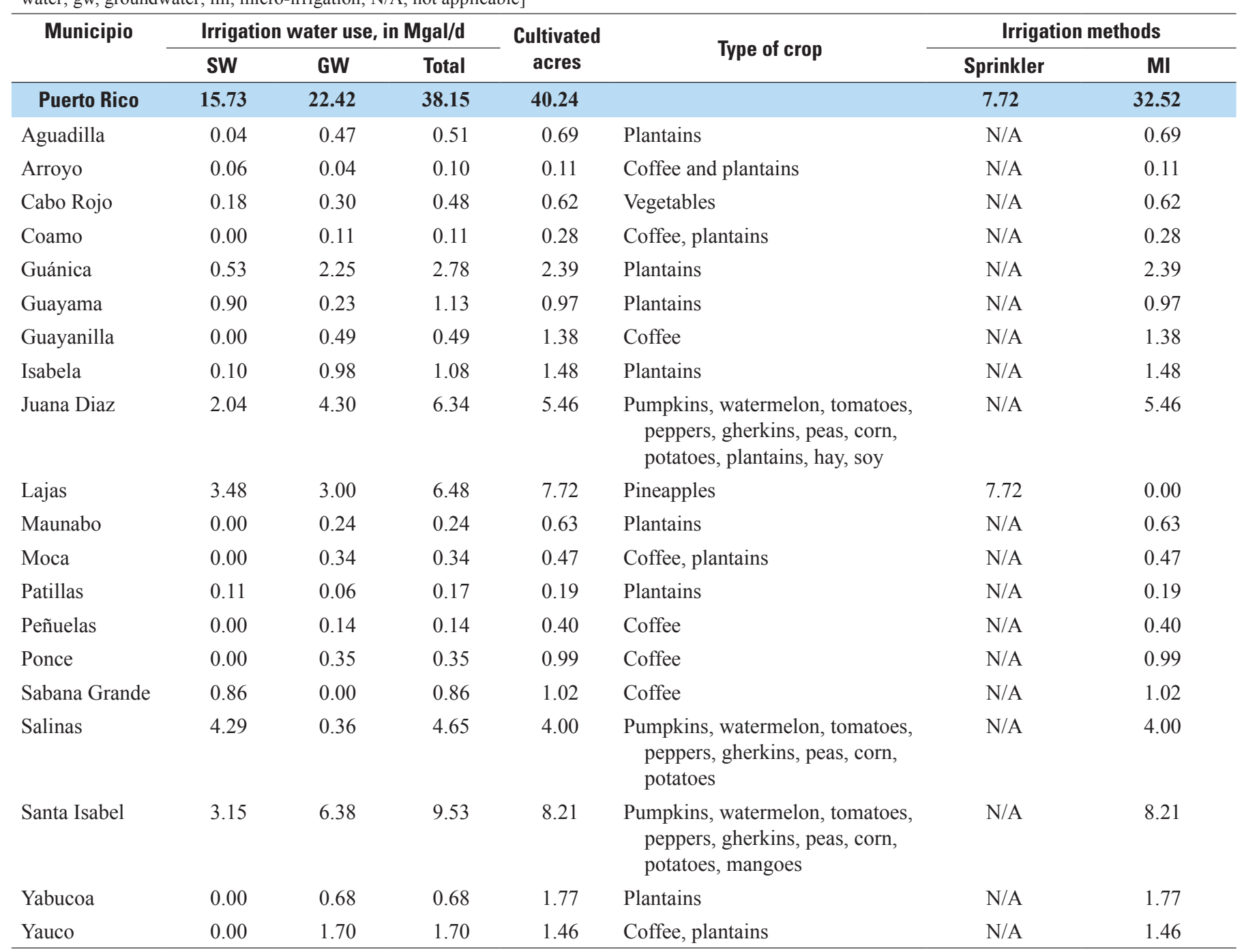


Table 6. Withdrawals and deliveries from public-supply water by public thermoelectric power plants in Puerto Rico by source and municipio, 2010.

[Source: U.S. Geological Survey, Caribbean Water Science Center; Mgal/d, million gallons per day; gWh, giga-watt hours]

\begin{tabular}{|c|c|c|c|c|c|c|c|c|}
\hline Municipio & Facility name & $\begin{array}{c}\text { Source of } \\
\text { saline water }\end{array}$ & $\begin{array}{c}\text { Fresh } \\
\text { groundwater } \\
\text { withdrawals, } \\
\text { in Mgal/d }\end{array}$ & $\begin{array}{c}\text { Fresh surface } \\
\text { water } \\
\text { withdrawals, } \\
\text { in Mgal/d }\end{array}$ & $\begin{array}{c}\text { Saline surface } \\
\text { water } \\
\text { withdrawals, } \\
\text { in Mgal/d }\end{array}$ & $\begin{array}{c}\text { Public- } \\
\text { supply water } \\
\text { deliveries, in } \\
\text { Mgal/d }\end{array}$ & $\begin{array}{c}\text { Withdrawals } \\
\text { and } \\
\text { deliveries, } \\
\text { in Mgal/d }\end{array}$ & $\begin{array}{l}\text { Power } \\
\text { genera- } \\
\text { tion, in } \\
\text { gWh }\end{array}$ \\
\hline Cataño & Palo Seco & $\begin{array}{c}\text { Ensenada } \\
\text { Boca } \\
\text { Vieja }\end{array}$ & 0.00 & 0.00 & 604.71 & 0.66 & 605.37 & $3,783.20$ \\
\hline Salinas & Aguirre & Jobos Bay & 0.76 & 0.00 & 563.68 & 0.00 & 564.44 & $4,794.94$ \\
\hline San Juan & San Juan & $\begin{array}{c}\text { San Juan } \\
\text { Bay }\end{array}$ & 0.00 & 0.00 & 503.62 & 1.11 & 504.73 & $2,866.92$ \\
\hline
\end{tabular}

Table 7. Water use and power generated by hydroelectric power plants in Puerto Rico by municipio, 2010.

[Source: U.S. Geological Survey, Caribbean Water Science Center]

\begin{tabular}{|c|c|c|c|c|}
\hline \multirow[b]{2}{*}{ Municipio } & \multirow[b]{2}{*}{ Facility name } & \multicolumn{2}{|c|}{$\begin{array}{c}\text { Instream water } \\
\text { use }\end{array}$} & \multirow{2}{*}{$\begin{array}{c}\text { Power } \\
\text { generation, } \\
\text { in gWh }\end{array}$} \\
\hline & & $\begin{array}{l}\text { Million } \\
\text { gallons } \\
\text { per day }\end{array}$ & $\begin{array}{l}\text { acre- } \\
\text { feet per } \\
\text { year }\end{array}$ & \\
\hline Puerto Rico & & 555.53 & 622,179 & 158.94 \\
\hline Arecibo & Dos Bocas & 340.33 & 381,166 & 51.43 \\
\hline Naguabo & Río Blanco & 2.87 & 3,219 & 3.24 \\
\hline Orocovis & Toro Negro 2 & 1.22 & 1,369 & 0.75 \\
\hline \multirow[t]{2}{*}{ Peñuelas } & Garzas 1 & 8.95 & 10,028 & 11.23 \\
\hline & Garzas 2 & 2.50 & 2,795 & 0.80 \\
\hline Utuado & Caonillas 1 & 104.93 & 117,524 & 49.57 \\
\hline Villalba & Toro Negro 1 & 7.87 & 8,816 & 9.07 \\
\hline \multirow[t]{2}{*}{ Yauco } & Yauco 1 & 32.96 & 36,910 & 19.92 \\
\hline & Yauco 2 & 53.89 & 60,353 & 12.93 \\
\hline
\end{tabular}

Table 8. Summary of total water use in Puerto Rico, 2010.

[Source: U.S. Geological Survey, Caribbean Water Science Center; Mgal/d, million gallons per day; gal/d, gallon per day

\begin{tabular}{|c|c|}
\hline 2010 Census of population, in thousands & $3,725.789$ \\
\hline $\begin{array}{l}\text { Population served by public-supply water systems, } \\
\text { in thousands }\end{array}$ & $3,687.792$ \\
\hline Public-supply water withdrawals, in Mgal/d & 677.21 \\
\hline Public-supply water deliveries, in Mgal/d & 662.58 \\
\hline $\begin{array}{l}\text { Public-supply per capita delivery, in gal/d per } \\
\text { person }\end{array}$ & 179.67 \\
\hline $\begin{array}{l}\text { Domestic use from public-supply water systems, } \\
\text { in } \mathrm{Mgal} / \mathrm{d}\end{array}$ & 205.77 \\
\hline Domestic per capita use, in gal/d per person & 55.80 \\
\hline Domestic self-supplied, in Mgal/d & 2.41 \\
\hline Industrial self-supplied, in Mgal/d & 4.30 \\
\hline Crop irrigation, in $\mathrm{Mgal} / \mathrm{d}$ & 38.16 \\
\hline Thermoelectric freshwater, in Mgal/d & 1.67 \\
\hline Total offstream freshwater withdrawals, in Mgal/d & 723.75 \\
\hline Surface water & 606.14 \\
\hline Groundwater & 117.61 \\
\hline Total instream water withdrawals, in $\mathrm{Mgal} / \mathrm{d}$ & $2,817.55$ \\
\hline Saline surface water & $2,262.02$ \\
\hline Fresh surface water & 555.53 \\
\hline
\end{tabular}


Table 9. Total freshwater withdrawals in Puerto Rico by offstream water-use categories and municipios, 2010.

[Source: U.S. Geological Survey, Caribbean Water Science Center; all values in million gallons per day; N/A, not applicable]

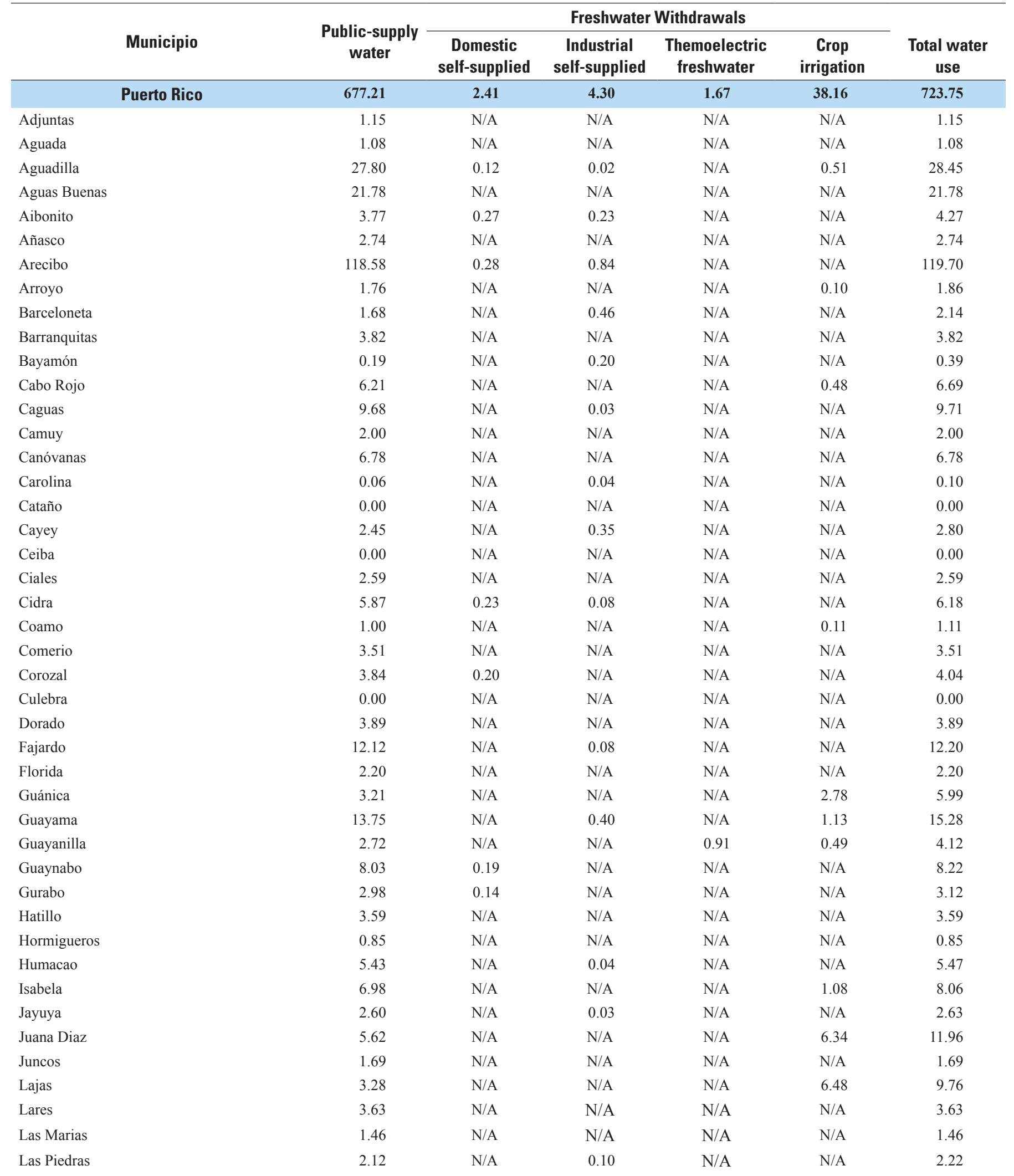


Table 9. Total freshwater withdrawals in Puerto Rico by offstream water-use categories and municipios, 2010.—Continued [Source: U.S. Geological Survey, Caribbean Water Science Center; all values in million gallons per day; N/A, not applicable]

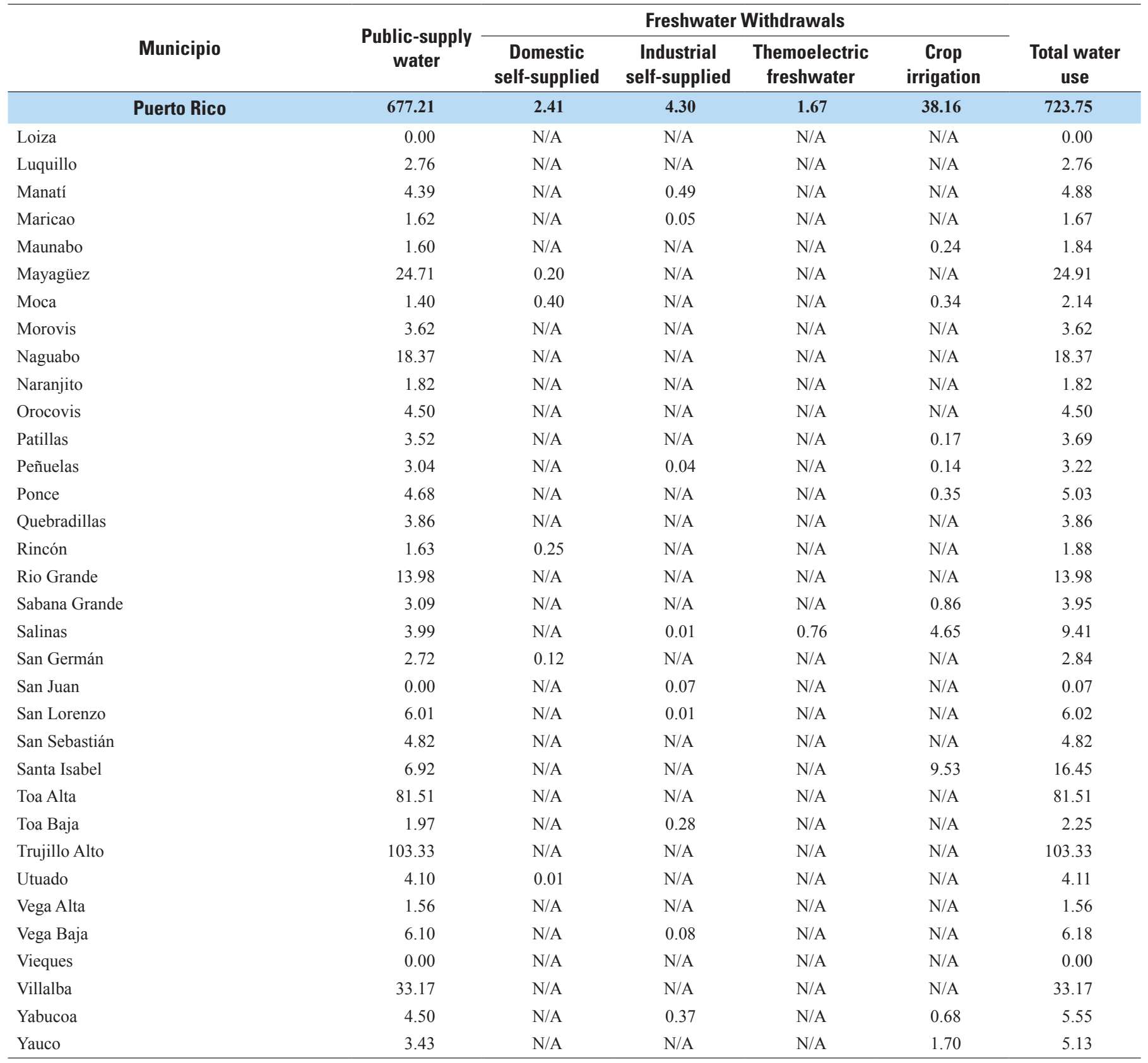




\section{Summary}

Water-use data for 2010 were aggregated by 78 municipios for public-supply water withdrawals and deliveries, domestic and industrial self-supplied, crop irrigation, and thermoelectric and hydroelectric power water use. Public-supply water withdrawals were compiled for the municipio in which the withdrawals take place; and the publicsupply water deliveries were aggregated by wards based in the population served by the public-supply water system. The data were compiled for five major offstream categories: public-supply water withdrawals and deliveries, domestic and industrial self-supplied water use, crop-irrigation water use, and thermoelectric-power freshwater use. One instream water-use category also was compiled: power-generation instream water use (thermoelectric saline withdrawals and hydroelectric power).

During 2010, public-supply water withdrawals from surface-water and groundwater sources constituted the major freshwater use category and were estimated at 677 million gallons per day (Mgal/d). The population served by publicsupply water facilities operated by the Puerto Rico Aqueduct and Sewer Authority (PRASA) was estimated to be 96 percent of the total resident population for Puerto Rico in 2010 (about 3,586 thousand residents). Non-PRASA public-supply water withdrawals were estimated at $7.1 \mathrm{Mgal} / \mathrm{d}$ to serve a population of about 102 thousand residents. Public-supply domestic water use in Puerto Rico was estimated at $206 \mathrm{Mgal} / \mathrm{d}$, with about 30 percent of the total PRASA deliveries from surface-water and groundwater sources. Water withdrawals by domestic self-supplied users were estimated at $2.41 \mathrm{Mgal} / \mathrm{d}$ by a population of about 38 thousand people. Groundwater withdrawals by industrial users were estimated at $4.30 \mathrm{Mgal} / \mathrm{d}$.

Crop-irrigation withdrawals from surface-water and groundwater sources were estimated at $38.2 \mathrm{Mgal} / \mathrm{d}$, of which $15.7 \mathrm{Mgal} / \mathrm{d}$ of surface water were in areas supplied by the public irrigation systems operated by the Puerto Rico Electric Power Authority. Groundwater withdrawals from Puerto Rico's major aquifers for irrigation purposes were about $22 \mathrm{Mgal} / \mathrm{d}$. Micro-irrigation was the predominant irrigation method (32.5 thousand of acres) to supply artificially the water requirements of 40.2 thousand cultivated acres.

In 2010, Puerto Rico had four thermoelectric powerplants that used large amounts of saline (seawater) for cooling. The instream saline withdrawals totaled 2,262 Mgal/d and produced $13,545 \mathrm{gWH}$ of electricity in 2010. Freshwater use at thermoelectric powerplants consisted of $1.77 \mathrm{Mgal} / \mathrm{d}$ delivered from the PRASA to the plants located in Cataño and San Juan and $1.15 \mathrm{Mgal} / \mathrm{d}$ from local aquifers at the Guayanilla and Salinas powerplants.

The nine active hydroelectric powerplants located throughout Puerto Rico had an instream freshwater use of $556 \mathrm{Mgal} / \mathrm{d}$ in 2010 and combined they generated $159 \mathrm{gWh}$ of electricity.

\section{References Cited}

Hutson, S.S., Barber, N.L., Kenny, J.F., Linsey, K.S., Lumia, D.S., and Maupin, M.A., 2004, Estimated use of water in the United States in 2000: Reston, Va., U.S. Geological Survey Circular 1268, $46 \mathrm{p}$.

Dopazo-Rodríguez, Teresa, and Molina-Rivera, W.L, 1995, Estimated water use in Puerto Rico, 1988-89:

U.S. Geological Survey Open-File Report 95-380, 31 p.

Molina-Rivera, W.L, 1998, Estimated water use in Puerto Rico, 1995: U.S. Geological Survey Open-File Report 98-276, 29 p.

Molina-Rivera, W.L, 2005, Estimated water use in Puerto Rico, 2000: U.S. Geological Survey Open-File Report 2005-1201, 26 p.

Molina-Rivera, W.L, and Dopazo-Rodríguez, Teresa, 1995, Estimated water use in Puerto Rico, 1986-87: U.S. Geological Survey Open-File Report 95-358, 30 p.

Molina-Rivera, W.L., and Gómez-Gómez, Fernando, 2008, Estimated water use in Puerto Rico, 2005: U.S. Geological Survey Open-File Report 2008-1286, 37 p.

Puerto Rico Aqueduct and Sewer Authority, 2009, PRASA Water Distribution Systems Assessment. A fact sheet prepared at requested by the Puerto Rico Aqueduct and Sewer Authority: Prepared by Malcom Pirnie, Consulting Engineers [variously paged].

Puerto Rico Aqueduct and Sewer Authority, 2010, Water Production Reports. Print-outs and electronic files prepared at requested by U.S. Geological Survey: Prepared by Puerto Rico Aqueduct and Sewer Authority Regional Offices [variously paged].

Puerto Rico Department of Health, 2010, Non-PRASA Systems Inventory: Prepared by Puerto Rico Department of Health, Potable Water Office, 14 p.

Puerto Rico Planning Board, 2010, Digital orthophotography for Puerto Rico: Proyecto Xplorah.

Torres-Sierra, Heriberto, and Avilés, Ada, 1986, Estimated water use in Puerto Rico, 1980-82: U.S. Geological Survey Open-File Report 85-557, 77 p.

U.S. Census Bureau, 2010, U.S Census Bureau announces 2010 Census Population Counts: Washington D.C., U.S. Department of Commerce, Bureau of the Census, accessed September 2013 at $h t t p: / / w w w . c e n s u s . g o v / 2010 c e n s u s / n e w s / r e l e a s e s$. 
U.S. Census Bureau, 2011, Census 2010 Data for Puerto Rico, American Fact Finder: Washington D.C., U.S. Department of Commerce, Bureau of Census, accessed November 2012 at http://factfinder2.census.gov.

U.S. Census Bureau, 2012, North American Industry Classification System, Pharmaceutical Preparation Manufacturing: Washington D.C., U.S. Department of Commerce, Bureau of Census, accessed June 2013 at http://www.census.gov/ cgi-bin/sssd/naics/naicsrch.

U.S. Department of Commerce, 2005, Climatological Data Annual Summary Puerto Rico and Virgin Islands: National Oceanic and Atmospheric Administration, Environmental Data Service, v. 051, no. 13, 22 p.

U.S. Department of Commerce, 2010, Climatological Data Annual Summary Puerto Rico and Virgin Islands: National Oceanic and Atmospheric Administration, Environmental Data Service, v. 056, no. 13, 24 p.

U.S. Environmental Protection Agency, 2012, Public Water Drinking Water: accessed June 2013 at http://water.epa.gov/infrastructure/drinkingwater/pws/ factoids.cfm.

U.S. Geological Survey, 2013, Water-resources data for the United States Water Year 2010 and 2011: accessed July 2013 at http://wdr.water.usgs.gov/.
For further information about this publication contact:

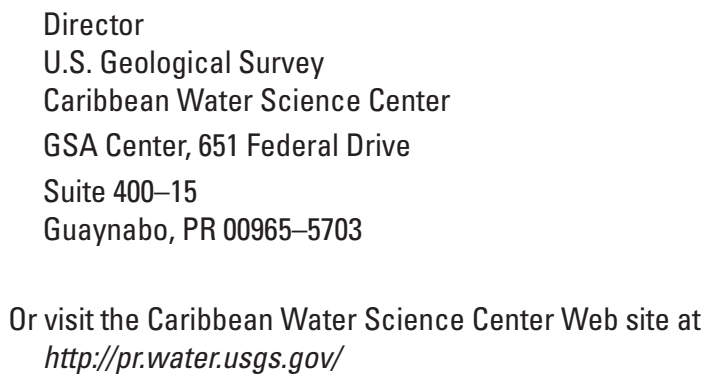

Or visit the Caribbean Water Science Center Web site at http://pr.water.usgs.gov/

Prepared by the Raleigh and Rolla Publishing Service Centers 

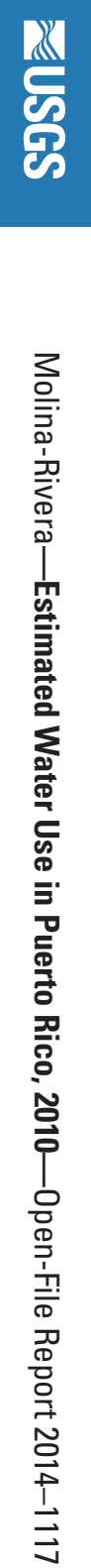